\title{
Structural geology of the southern Sheeprock Mountains, Utah: Regional significance
}

\author{
Nicholas Christie-Blick \\ Exxon Production Research Co. \\ P.O. Box 2189 \\ Houston, Texas 77001
}

\begin{abstract}
The Sheeprock Mountains are part of a horst of Proterozoic, Paleozoic and Cenozoic sedimentary and igneous rocks located in the transitional region between the Cordilleran fold-thrust belt and the hinterland in the Basin-Range province of west-central Utah.

Prominent structural elements in the Sheeprock Mountains are the Sheeprock Thrust, juxtaposing Proterozoic rocks above Paleozoic ones with a stratigraphic separation exceeding $10 \mathrm{~km}$; the Pole Canyon Thrust, thought to be an upper plate imbrication of the Sheeprock Thrust; the Pole Canyon Anticline, a recumbent fold vergent to the northeast and cut by the Pole Canyon Thrust; the east-northeaststriking Indian Springs (tear) Fault; and two low-angle normal faults (the Harker and Lion Hill Faults) which together account for stratigraphic omission of several kilometres.

The Pole Canyon Anticline is thought to have developed in the late Mesozoic during propagation of the thrusts parallel to the Indian Springs Fault, and this transport direction is corroborated by minor structures. Fault geometry suggests that the Harker and Lion Hill Faults are younger than the thrusts and probably of late Cenozoic age, although some mid-Cenozoic or even earlier displacement cannot be entirely ruled out.

My preferred interpretation of the structural history of the Sheeprock Mountains is consistent with minimal regional extension before the mid-Cenozoic and with the view that crustal shortening in the fold-thrust belt is for the most part unrelated to hinterland extension.
\end{abstract}

\section{INTRODUCTION}

The Sheeprock Mountains are part of a northwest- to north-trending horst of little-metamorphosed Upper Proterozoic $^{1}$ to Paleozoic and Cenozoic sedimentary and igneous rocks in the Basin-Range province of west-central Utah (Fig. 1). The internal structure of the range is dominated by low-angle faults. Some place older rocks on younger ones, and with one possible exception are thrusts.

Upper Proterozoic is used in the sense of Harrison and Peterman (1980), referring to the interval between 900 and $570 \mathrm{Ma}$ ago. Symbols used on figures in this paper are based on the approximately equivalent term of the U.S. Geological Survey, Proterozolc-Z (James, 1972, 1978), which embraces the interval from 800 to $570 \mathrm{Ma}$ ago.
Other low-angle faults place younger rocks on older ones, with stratigraphic omission, and are inferred to have been produced by extension. The Sheeprock Mountains are therefore transitional, both geographically and structurally, between the Cordilleran fold-thrust belt to the east (see King, 1969) and a hinterland of open folds, metamorphic core complexes and predominantly extensional structures to the west (Armstrong, 1972; Coney, 1980).

This paper has three objectives: (1) to provide an upto-date description of the structure of the southern Sheeprock Mountains; (2) to present new interpretations of the structural history; and (3) to consider how structural rela- 


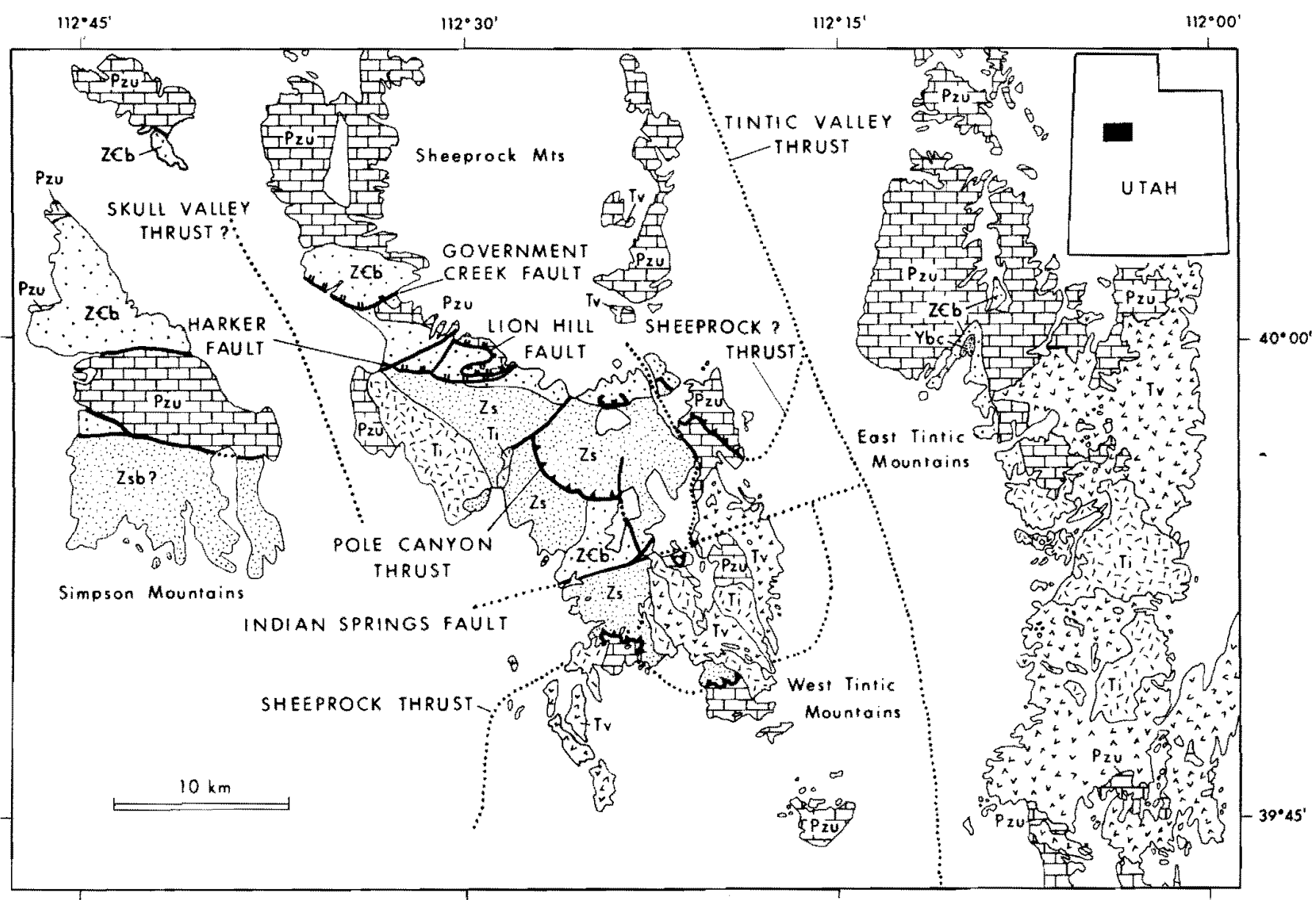

Figure 1. Location map of the Sheeprock Mountains in west-central Utah showing major faults and gross rock units (modified from Cohenour, 1959; Stokes, 1963; Morris, 1977; Moore and Sorensen, 1979). Faults (bold contacts, dotted where concealed): thrust (sawteeth on upper plate); low-angle extension fault (double ticks on hanging-wall block); high-angle fault (no ornament). Rock units: Ybc, Big Cottonwood(?) Formation (Proterozoic-Y); Zs, Sheeprock Group (Proterozoic-Z); ZCb, Brigham Group (Proterozoic-Z to Cambrian); Zsb, undifferentiated Sheeprock and Brigham Groups; Pzu, undifferentiated Paleozoic rocks; Ti, Tertiary intrusive rocks including intrusion breccia (large body on southwestern flank of Sheeprock Mountains is Sheeprock Granite); Tv, Tertiary extrusive rocks; unpatterned area, undifferentiated Tertiary and Quaternary sediments.

tions in the Sheeprock Mountains bear on the continuing controversy about the relation between thrusts and lowangle normal faults in the Basin-Range province (e.g., Armstrong, 1972; Crittenden, 1979; Compton and Todd, 1979; Coney, 1980; Allmendinger and Jordan, 1981; Wernicke, 1982).

Conclusions presented here are based largely on geologic mapping at 1:24,000 scale of the southern Sheeprock Mountains between latitudes $40^{\circ} 00^{\prime}$ and $39^{\circ} 54^{\prime} \mathrm{N}$. by Blick (1979), and of the southernmost part of the range and adjacent West Tintic Mountains by Morris and Kopf (1970a, 1970b).

\section{TERMINOLOGY OF LOW-ANGLE FAULTS}

It is now widely recognized that low-angle faults can originate in both extensional and contractional regimes, but there is no consensus about terminology appropriate for such faults. Purely descriptive terms are useful in the initial stages of geologic mapping, but genetic terms are desirable as we formulate kinematic interpretations of structural history. This is especially the case where rocks have been folded and faulted at different times and where faults initiated under one stress regime have been reactivated under a different regime (Dahlstrom, 1970; Arm- 
strong, 1972). In these cases, the relative ages of hanging-wall and footwall blocks at a particular locality may be a fallible guide to fault genesis. For example, Figure 2, based on faults in the Sheeprock Mountains, illustrates how reverse fault geometry ${ }^{2}$ can locally arise from normal slip (and hypothetically, vice versa) if reference surfaces are appropriately folded or tilted prior to fault movement. However, crustal extension and contraction can generally be distinguished from observations of structural relations over a large area, providing the timing of deformation is known.
GEOMETRY

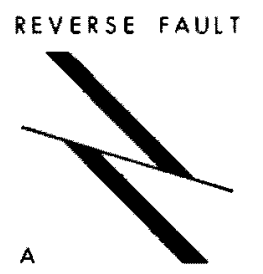

NORMAL FAULT

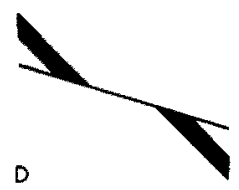

GENESIS
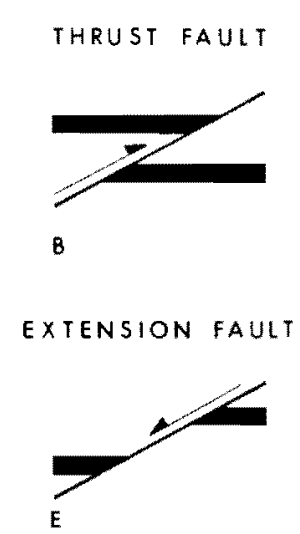
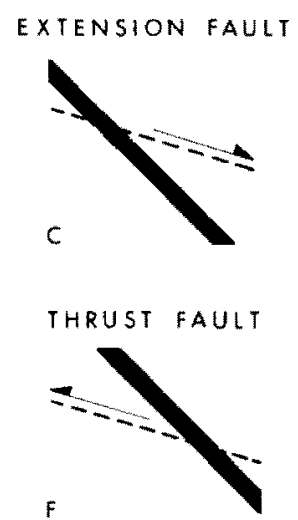

Figure 2. Vertical views of a low-angle reverse fault (A) and a low-angle normal fault (D) transverse to fault strike, and their genesis as either thrusts ( $B$ and $F$ ) or extension faults ( $C$ and $E$ ). It is assumed that in each case all separation is achieved on the fault illustrated by slip in the plane of the page. In cases B and $E$, faulted beds are subsequently folded or tilted, whereas in $C$ and $F$, folded or tilted beds are subsequently offset by a fault.

Among descriptive terms for gently dipping faults, those indicating the relative age of juxtaposed rocks are probably most useful, although somewhat unwieldy (e,g., low-angle reverse fault, low-angle normal fault, older-overyounger fault, younger-over-older fault). Other terms used recently in the Basin-Range province are imprecisely defined or not particularly descriptive, and some have assumed genetic implications that may be inappropriate in the Sheeprock Mountains (R. G. Bohannon, 1982, personal commun.). For example, "dislocation surface" (Rehrig and Reynolds, 1980) is practically synonymous with fault; "detachment fault" and its synonym "décollement" imply that rocks above and below the fault are characterized by independent styles of deformation (de Sitter, 1964; Bates and Jackson, 1980; Davis and others, 1980); the term "denuda-

${ }^{2}$ Following Hill (1959) and Crowell (1959), in this paper "reverse fault" and "normal fault" are geometric terms describing dip separation. A fault that dips less steeply than bedding is here termed a normal fault if younger rocks are juxtaposed on older ones, and a reverse fault if the opposite is true. tion fault" (Moores and others, 1970; Armstrong, 1972) seems to imply erosion or exposure of lower plate rocks as a result of fault movement.

In this paper, conspicuous low-angle faults in the Sheeprock Mountains are interpreted as "thrusts" and "extension faults," defined kinematically as suggested by McClay (1981). ${ }^{3}$ A thrust is a map scale contraction fault which shortens an arbitrary datum, commonly but not necessarily bedding. An extension fault extends an arbitrary datum such as bedding. As noted above, not all thrust segments are reverse faults (e.g., Fig. 2D, 2F) and not all extension faults are normal faults (Fig. 2A, 2C), because bedding may not be an appropriate datum in rocks that are already deformed. Observations, other than the relative age of juxtaposed rocks, such as fold vergence and the timing of deformation, may bear on fault interpretation. However, in spite of possible ambiguities, the terms "thrust" and "extension fault" are valuable, because they allow two genetically distinct classes of fault to be distinguished in interpretations without invoking any particular regional model.

The kinematic terms "normal-slip fault" and "reverseslip fault" (Hill, 1959), though valid, are avoided in this paper, because where applied to tilted or folded faults, it is unclear whether normal and reverse refer to the orientation of the fault during displacement or to its present orientation.

\section{PREVIOUS WORK}

Early descriptions of rocks in the Sheeprock and adjacent West Tintic Mountains are by Loughlin (1920), Eardley and Hatch (1940), Stringham (1942) and Gardner (1954). The stratigraphy was established in a definitive work by Cohenour (1959), and his scheme was largely followed by Groff (1959) and by Morris and Kopf (1967, 1970a, 1970b). Harris (1958) independently established an alternative terminology for Proterozoic rocks in the vicinity of Dutch Peak (see Fig. 3 for location), but there are difficulties with his nomenclature as a result of structural complications, which he did not fully understand (ChristieBlick, 1982). The stratigraphy of Upper Proterozoic and Lower Cambrian rocks, which underlie much of the southern Sheeprock Mountains (Fig. 1), has been revised extensively by Christie-Blick (1982), in part, based on new understanding of the geologic structure. This paper therefore constitutes a companion to the stratigraphic summary presented in Christie-Blick (1982).

Essential features of the structure of the Sheeprock Mountains have been known for many years. Loughlin (1920) recognized that in the northern part of the Cherry Creek Quadrangle (Fig. 3), Proterozoic quartzite is juxtaposed by a thrust above Paleozoic limestone. The fault, any dip.

${ }^{3}$ The terms "thrust" and "extension fault" may be applied to faults of 


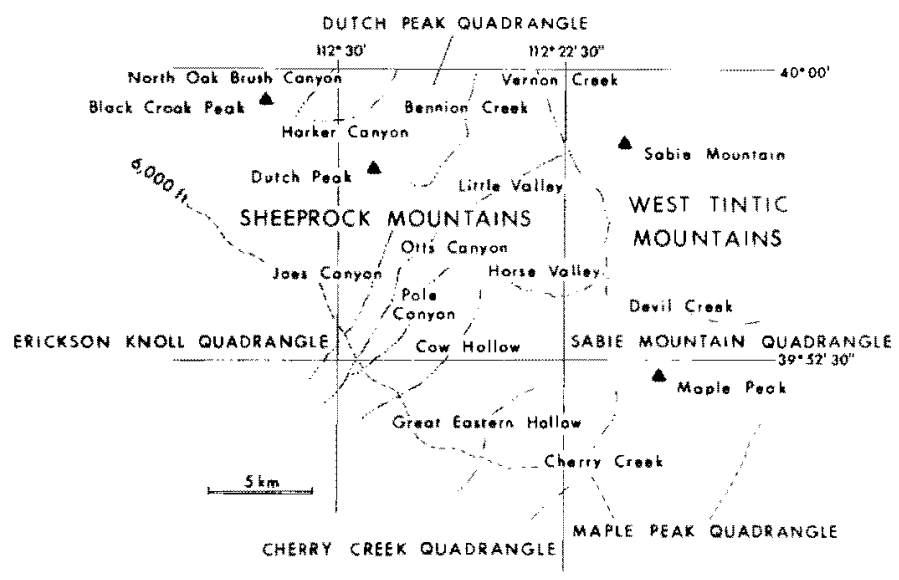

Figure 3. Topographic features of the southern Sheeprock Mountains and adjacent part of the West Tintic Mountains mentioned in this paper. The ranges are separated by Vernon Creek and Cherry Creek.

named the Sheeprock Thrust by Eardley (1939), was subsequently delineated in mapping by Stringham (1942), Gardner (1954), Cohenour (1959), Groff (1959), and Morris and Kopf (1970a, 1970b) (Figs. 1, 4). Near the drainage divide of the southern Sheeprock Mountains, Cohenour (1959) mapped and named the Pole Canyon Thrust (Figs. $1,4)$, which he regarded as structurally above the Sheeprock Thrust. However, Harris (1958) and later Armstrong (1958) interpreted the two faults as one. Cohenour (1959) was the first to recognize that beds beneath the Pole Canyon Thrust are overturned and dip toward the west, whereas upper plate rocks are mostly upright and dip to the northeast. He also established the presence of a major steeply dipping fault between the traces of the Pole Canyon and Sheeprock Thrusts, which Morris and Kopf (1967) termed the Indian Springs Fault. Groff (1959) and Morris and Kopf (1970a) interpreted this fault as a tear, although they disagreed about its slip sense, whereas Armstrong (1968) considered it another segment of a folded Sheeprock Thrust. In the northern part of the Sheeprock Mountains, Cohenour (1959) recognized and named the Government Creek Fault (Fig. 1), a third fault that juxtaposes older rocks above younger ones, but a fault that he considered to have moved by strike slip. In addition to these faults that repeat the stratigraphic section, Cohenour (1959) also mapped several (including the Lion Hill "Thrust"; Figs. 1, 4) that attenuate it. However, as was standard procedure at the time, he regarded all gently dipping faults (except the Government Creek Fault) as thrusts whatever the relative age of hanging-wall and footwall blocks.

\section{STRATIGRAPHY}

The Sheeprock Mountains are underlain by a miogeoclinal section of little-metamorphosed Upper Protero- zoic to Lower Cambrian clastic sedimentary rocks and Paleozoic carbonate rocks with an aggregate thickness of over 12,500 m (Fig. 5; Hintze, 1973; Christie-Blick, 1982). The southern flank of the range and much of the adjacent West Tintic Mountains are overlain and intruded by Oligocene(?) to Miocene volcanic and plutonic rocks (Fig. 1; Morris and Kopf, 1967, 1970a, 1970b).

The Upper Proterozoic to Lower Cambrian beds are as thick as 7,200 $\mathrm{m}$ in the southern Sheeprock Mountains, and Christie-Blick (1982) has suggested detailed correlations with formations established in northern Utah and southeastern Idaho by Crittenden and others (1971). The Sheeprock sequence begins at the base with 2,700 to 4,300 $\mathrm{m}$ of phyllite, quartzite, glaciomarine diamictite and shale assigned to the Otts Canyon, Dutch Peak, and Kelley Canyon Formations of the Sheeprock Group (Fig. 5). These units are overlain by 1,950 to $4,000 \mathrm{~m}$ of quartzite and minor shale assigned to the Caddy Canyon Quartzite, Inkom and Mutual(?) Formations and Prospect Mountain Quartzite, which together constitute the Brigham Group. Details about regional and local lateral variations of thickness and facies within these rocks may be found in Blick (1979), Christie-Blick (1982), and Crittenden and others (1983).

The Proterozoic stratigraphy in the Sheeprock Mountains, although relatively coherent for more than $350 \mathrm{~km}$ to the north, is markedly different from that in the East Tintic Mountains, only $20 \mathrm{~km}$ to the east (Fig. 1). There, Lower Cambrian Tintic Quartzite overlies $510 \mathrm{~m}$ of quartzite and shale, correlated by Morris and Lovering (1961) with the Middle Proterozoic Big Cottonwood Formation. Upper Proterozoic rocks, thicker than $6,000 \mathrm{~m}$ in the Sheeprock Mountains, are apparently missing at a contact interpreted to be a regional unconformity. This stratigraphic contrast, along with differences in the thickness and facies of Upper Ordovician to Devonian carbonate rocks (Morris and Kopf, 1969), suggests several tens of kilometres displacement on the intervening but mostly concealed Tintic Valley Thrust (Morris, 1977).

Proterozoic rocks of the Sheeprock Mountains also differ from those of the southern Simpson Mountains, about $10 \mathrm{~km}$ to the west (Fig. 1), where Thomas (1958) described a sequence estimated by H. T. Morris (1978, personal commun.) to be about $5,000 \mathrm{~m}$ thick. The age of this sequence is uncertain, but at least two interpretations are possible (Blick, 1979). One is that the rocks of the Simpson Mountains are temporally equivalent to the Sheeprock and Brigham Groups. Lateral facies changes implicit in this correlation are somewhat abrupt, suggesting the presence of an intervening thrust, perhaps the Skull Valley Thrust of Roberts and others (1965) (Fig. 1). For example, graywacke of unit I of Thomas (1958) may be equivalent to the upper part of the Dutch Peak Formation; unit II (siltstone and shale), to the Kelley Canyon Formation; and unit $\mathrm{V}$ 


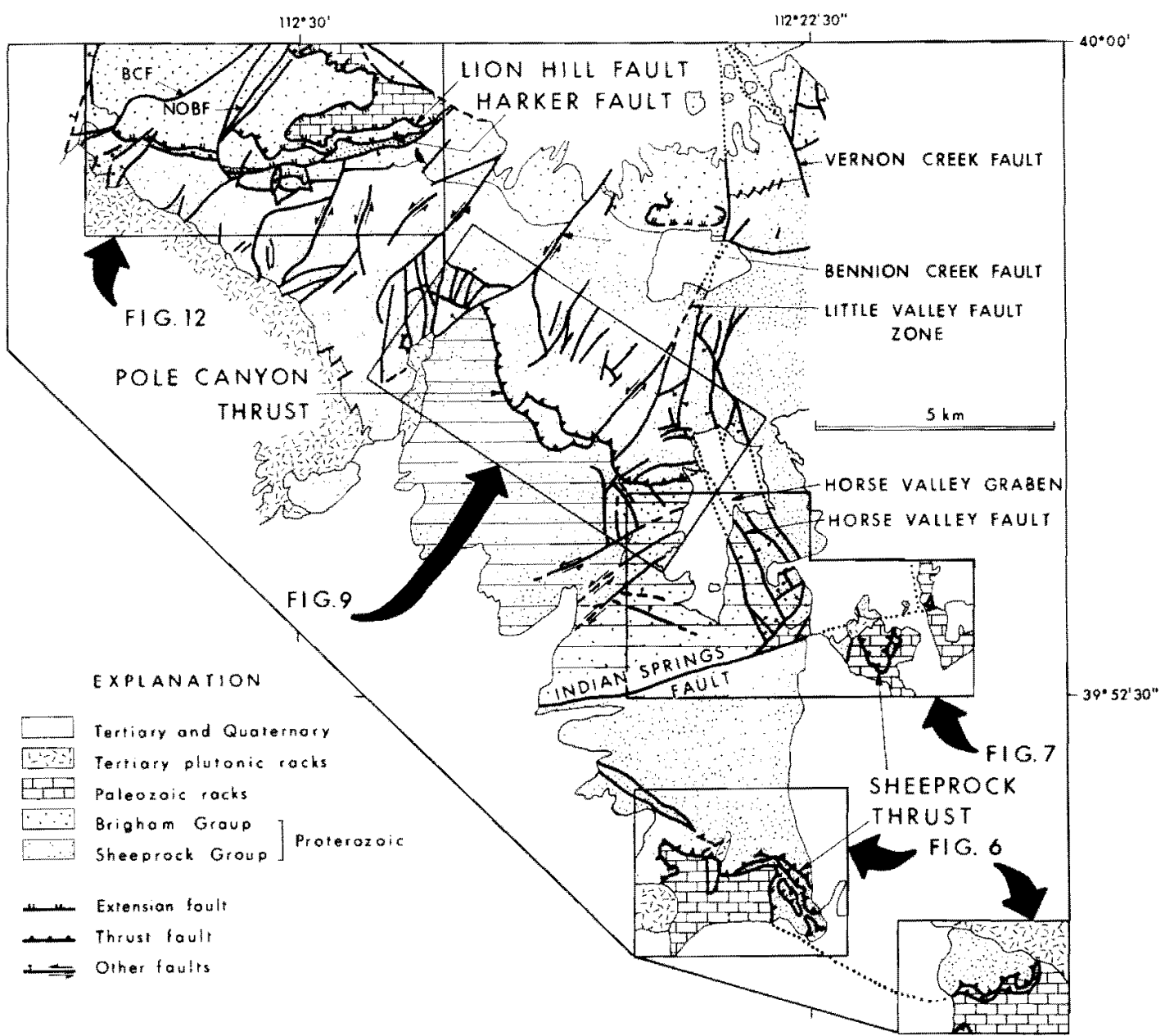

Figure 4. Simplified fault map of the southern Sheeprock Mountains, indicating the location of more detailed geologic maps illustrated in Figures 6, 7, 9, 12 (after Blick, 1979, and unpublished mapping; Morris and Kopf, 1970a, 1970b). Horizontal ruling indicates overturned rocks between the Sheeprock and Pole Canyon Thrusts. Abbreviations for faults: BCF, Black Crook Fault; NOBF, North Oak Brush Fault.

(quartzite), to the Caddy Canyon Quartzite. Siltstone and sandstone of unit IV resemble the Papoose Creek Formation of Crittenden and others (1971), but that formation is poorly developed in the Sheeprock Mountains (Christie-
Blick, 1982). Units III (quartzite) and VI (mainly argillite) are unknown in the Sheeprock Mountains. A second interpretation is that the Simpson Mountains sequence is correlative with the Middle Proterozoic Big Cottonwood Formation as in the East Tintic Mountains. However, such a correlation implies exhumation to a structurally very deep level in comparison with adjacent ranges. If Middle Proterozoic, the Simpson Mountains sequence should either stratigraphically underlie a thick section of Upper Proterozoic and Paleozoic rocks, comparable to that in the Sheeprock Mountains, or occur structurally beneath the Tintic Valley and/or Sheeprock Thrusts. Note that this lat- ter possibility might involve unrealistically large displacements on these thrusts (see Fig. 1 for scale).

Paleozoic beds overlying the Prospect Mountain Quartzite in the Sheeprock Mountains are at least 5,300 m thick even if the incomplete section of PennsylvanianPermian Oquirrh Group is excluded (Hintze, 1973). Paleozoic rocks are best exposed in the northern Sheeprock Mountains (Fig. 1; Cohenour, 1959), but they also occur in the southernmost part of the range, in the lower plate of the Sheeprock Thrust (Morris and Kopf, 1970a, 1970b). The Cambrian beds consist of thin shale and limestone with minor quartzite $(340 \mathrm{~m})$, overlain by thick limestone and dolomite $(1,400 \mathrm{~m})$, and have been subdivided into 12 formations (Fig. 5; Cohenour, 1959; Hintze, 1973). The Ordovician rocks in the northern Sheeprock Mountains include, from oldest to youngest, argillaceous and sandy limestone 


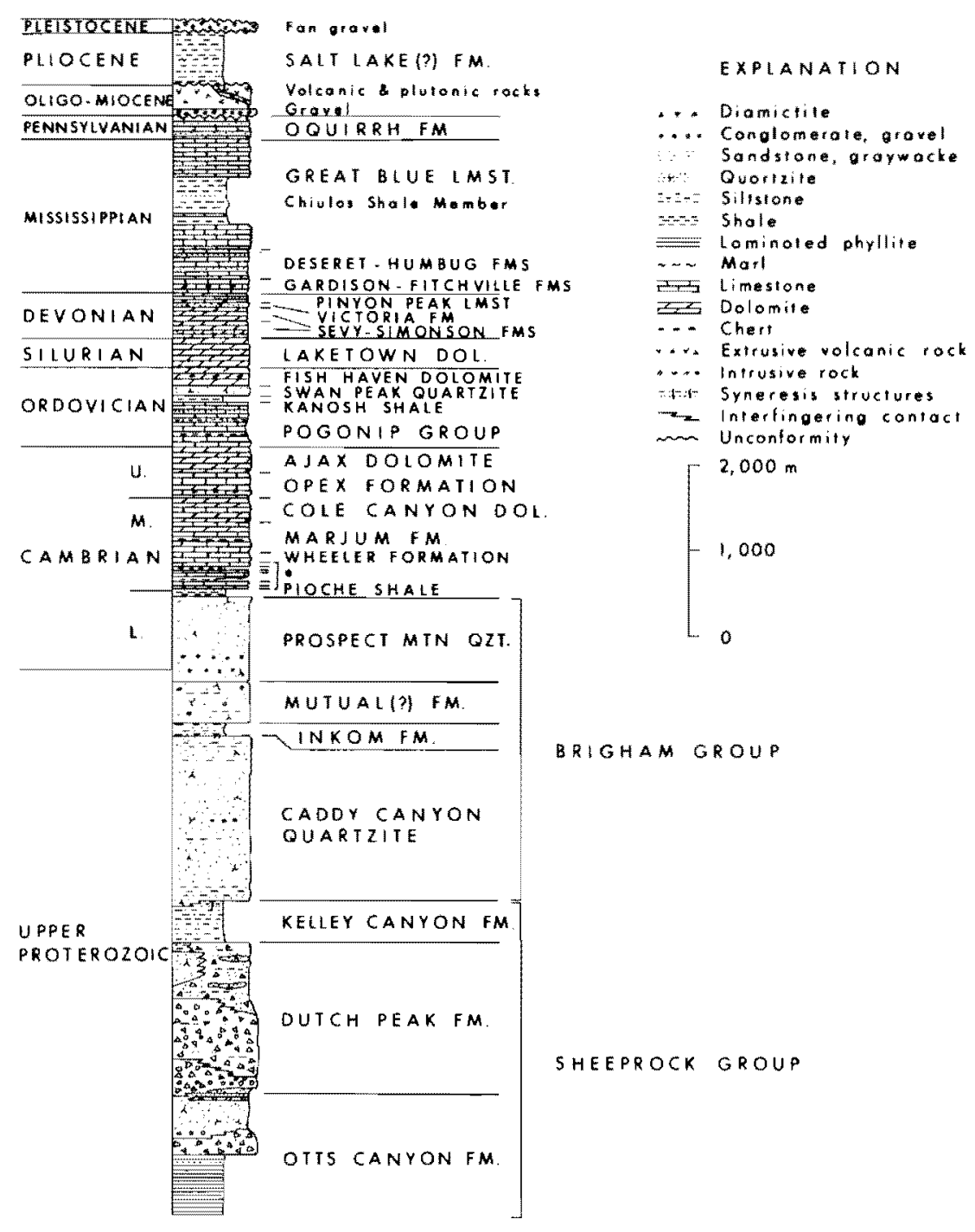

Figure 5. Composite stratigraphy of the Sheeprock and West Tintic Mountains (simplified from Hintze, 1973; Christie-Blick, 1982). *Unlabeled Cambrian formations between the Pioche Shale and the Wheeler Formation, from oldest to youngest: Tatow Formation, Millard-Howell Limestone, Chisholm Shale, Dome Limestone, Whirlwind Formation, and Swasey Limestone. Note that the Cambrian stratigraphy may require revision in the light of the work of Hintze and Robison (1975) in the House Range, $100 \mathrm{~km}$ southwest of the Sheeprock Mountains.

of the Pogonip Group $(520 \mathrm{~m})$, the Kanosh Shale $(75 \mathrm{~m})$, the Swan Peak Quartzite ( 100 to $140 \mathrm{~m}$ ), and the Fish Haven Dolomite $(215 \mathrm{~m})$. A comparable but incomplete and faulted Ordovician section, totaling $1,165 \mathrm{~m}$, occurs in the lower plate of the Sheeprock Thrust (Groff, 1959; Morris and Kopf, 1970a, 1970b). The Silurian is thin (275 to $430 \mathrm{~m})$ and is represented by a single formation, the Laketown Dolomite. From oldest to youngest, the Devonian consists of the Sevy Dolomite and Simonson Dolomite (together about 250 to $450 \mathrm{~m}$ ), quartzite of the Victoria Formation and the Pinyon Peak Limestone, together about $175 \mathrm{~m}$ thick in the northern Sheeprock Mountains, but only $70 \mathrm{~m}$ thick beneath the Sheeprock Thrust (Hintze, 1973; Morris and Kopf, 1970a, 1970b). The Mississippian is thick $(1,800 \mathrm{~m})$ and mostly limestone, except for the Chiulos Shale Member $(550 \mathrm{~m})$ of the Great Blue Formation (Fig. 5). The Pennsylvanian section is not complete in the Sheeprock Mountains.

Deformed Proterozoic and Paleozoic strata are unconformably overlain and intruded by various volcanic and plutonic rocks which from regional arguments are of probably Oligocene to Miocene age (McKee, 1971; Lipman and 
others, 1972; Lindsey and others, 1975). These igneous rocks include latite; quartz latite; monzonite and quartz monzonite porphyry; quartz diorite porphyry; aplite in dikes, sills and plugs; olivine basalt dikes and one flow; rhyolitic tuff; and intrusion breccias of both rhyolitic and andesitic composition (Morris and Kopf, 1967, 1970a, 1970b). The total thickness of extrusive volcanic rocks is several hundred metres. The Sheeprock Granite, which intrudes the southwest side of the Sheeprock Mountains (Fig. 1; Cohenour, 1959) is of Early Miocene age (17 to $19 \mathrm{Ma}$ by the $\mathrm{K}-\mathrm{Ar}$ method on biotite and 15 to $20 \mathrm{Ma}$ from lead-alpha determinations on zircon; Armstrong, 1970, and quoted in Cohenour, 1970). These igneous rocks are unconformably overlain by lacustrine silt, marl, and bentonitic tuff of the Salt Lake(?) Formation $(600 \mathrm{~m}$ ?) and by Pleistocene to Holocene alluvial fan gravel, mudflow deposits, alluvium, lake deposits, and aeolian sand (Morris and Kopf, 1970a, 1970b).

\section{STRUCTURE}

The internal structure of the southern Sheeprock Mountains is dominated by low-angle faults. Those with significant stratigraphic separation are the Sheeprock and Pole Canyon Thrusts ${ }^{4}$ and the Harker and Lion Hill (normal) Faults. Several steeply dipping faults are inferred to be tears. Of these, the Indian Springs Fault is most conspicuous. With the exception of overturned beds beneath the Pole Canyon Thrust, the Pole Canyon Anticline of Cohenour (1959), folds are subordinate and for the most part of mesoscopic scale.

\section{Sheeprock Thrust}

The Sheeprock Thrust is best exposed in the Cherry Creek and Maple Peak Quadrangles (Figs. 3, 4, 6; Morris and Kopf, 1970a, 1970b), where it was first recognized by Loughlin (1920). It consists of several anastomosing strands with fault dips ranging from near zero to as much as $50^{\circ}$ northward. Between Great Eastern Hollow and Cherry Creek (located in Fig. 3), the thrust juxtaposes gently dipping rocks of the Proterozoic Otts Canyon and Dutch Peak Formations above steeply dipping and overturned strata of the Lower Ordovician Pogonip Group through Upper Mississippian Deseret Limestone (Fig. 5). About $2 \mathrm{~km}$ east of Cherry Creek in the southern West Tintic Mountains, the Otts Canyon and Dutch Peak Formations are faulted against Upper Mississippian Great Blue Limestone, a stratigraphic separation exceeding $10 \mathrm{~km}$.

Two small klippen, apparently separated by the concealed eastward extension of the Indian Springs Fault,

II continue to use the term "thrust" in these well-established names in spite of genetic connotations, because there is little doubt that these faults were responsible for significant crustal shortening. occur in the southwestern corner of the Sabie Mountain Quadrangle (Figs. 3, 4, 7). The southern klippe consists of gently dipping Paleozoic carbonate rocks in thrust contact above overturned Deseret Limestone that dips gently to the north and northwest (Morris and Kopf, 1970b). Slices of Dutch Peak Formation are included in the fault zone, along with quartzite here interpreted as Otts Canyon Formation, by analogy with exposures of the Sheeprock Thrust in the Cherry Creek and Maple Peak Quadrangles. Note, however, that Morris and Kopf (1970b) assigned the quartzite to the upper Sheeprock Series (Caddy Canyon Quartzite in this paper). The northern klippe illustrated in Figure 7 consists of quartzite, similarly interpreted as Otts Canyon Formation, faulted above Great Blue Formation. The fault beneath both klippen is thought to be the Sheeprock Thrust for reasons discussed below (see the cross section in Fig. 8).

In the vicinity of Sabie Mountain in the northern West Tintic Mountains (Figs. 1, 3), another thrust strand entirely within the Paleozoic section is possibly also part of the Sheeprock Thrust (Groff, 1959; Morris, 1977). I have not studied the geology of that area.

\section{Pole Canyon Thrust}

The trace of the Pole Canyon Thrust extends for about $6 \mathrm{~km}$ from Bennion Creek to the northern part of Horse Valley across the drainage divide of the Sheeprock Mountains (Figs. 3, 4, 9). For most of its exposed length, the thrust is relatively planar, and its dip ranges from $12^{\circ}$ north-northeast in Pole Canyon to $20^{\circ}$ east-northeast on the ridge south of Bennion Creek. Between the northern parts of Otts and Pole Canyons, a subsidiary upper strand dips to the northeast at $40^{\circ}$ to $50^{\circ}$ (Fig. 10). However, contrary to mapping by Cohenour (1959, cross section

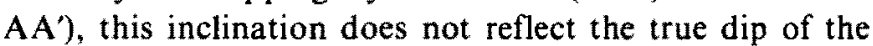
main strand of the thrust.

In the vicinity of Bennion Creek, Cohenour (1959) thought that the Pole Canyon Thrust was folded and locally near-vertical, whereas $I$ interpret the thrust to be offset by a steeply dipping fault, here named the Bennion Creek Fault (Fig. 9). The new interpretation is based on careful mapping of fault traces and the observation that lower plate rocks are not correspondingly deformed along with the supposedly folded thrust. Only upper plate rocks are exposed on the west side of the Bennion Creek Fault, except in a small window intruded by the Sheeprock Granite at the head of Joes Canyon (Fig. 9).

Where exposed, the Pole Canyon Thrust cuts only Proterozoic rocks and juxtaposes Otts Canyon Formation above rocks as young as Caddy Canyon Quartzite, a stratigraphic separation of only 2 to $3 \mathrm{~km}$. As noted by Cohenour (1959), upper plate rocks for the most part dip steeply to the north and northeast, whereas strata of the lower 
$112^{*} 22^{\prime} 30^{\prime \prime}$
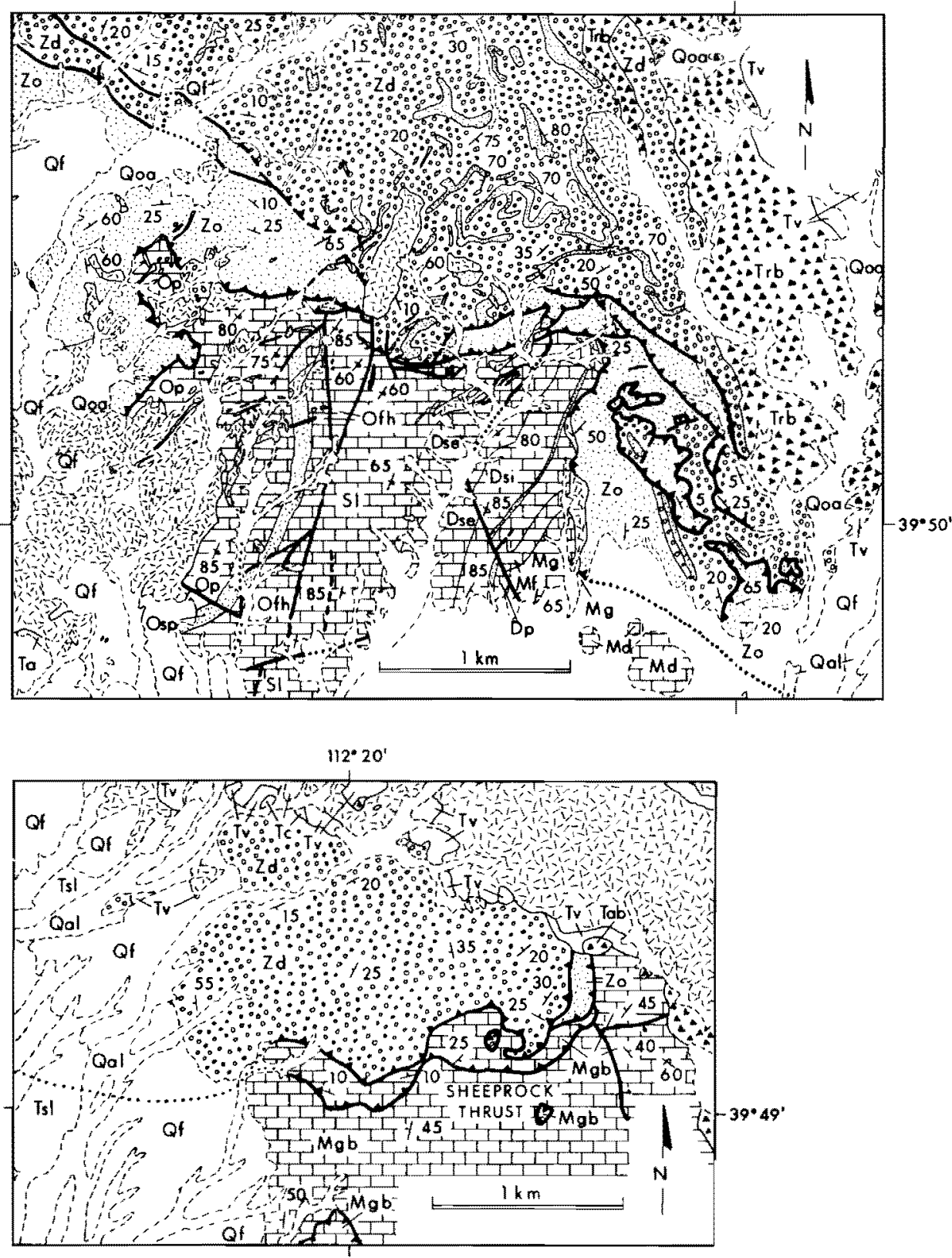

Figure 6. Geologic maps of parts of the Cherry Creek and Maple Peak Quadrangles, showing the trace of the Sheeprock Thrust (simplified from Morris and Kopf, 1970a, 1970b). See Figure 4 for location. Faults (bold contacts, dashed where approximately located, dotted where concealed): thrust (sawteeth on upper plate); high-angle fault (no ornament). Stratigraphic units: Zo, Otts Canyon Formation; Zd, Dutch Peak Formation, with quartzite beds and lenses indicated by stipple pattern; Op, Pogonip Group; Osp, Swan Peak Formation; Ofh, Fish Haven Dolomite; Sl, Laketown
Dolomite; Dse, Sevy Dolomite; Dsi, Simonson Dolomite; Dp, Pinyon Peak Limestone, with quartzite member indicated by stipple pattern; Mf, Fitchville Formation; Mg, Gardison Limestone; Md, Deseret Limestone; Mgb, Great Blue Formation; Tc, Tertiary conglomerate; $T v$, latite and quartz latite volcanic rocks; Ta, andesite or latite; Tab, andesite intrusion breccia; Trb, rhyolitic intrusion breccia; random dash pattern, undifferentiated Tertiary plutonic rocks; Tsl, Salt Lake Formation; Qf, Qoa, and Qal, Quaternary fan gravel, older alluvium, and alluvium. 


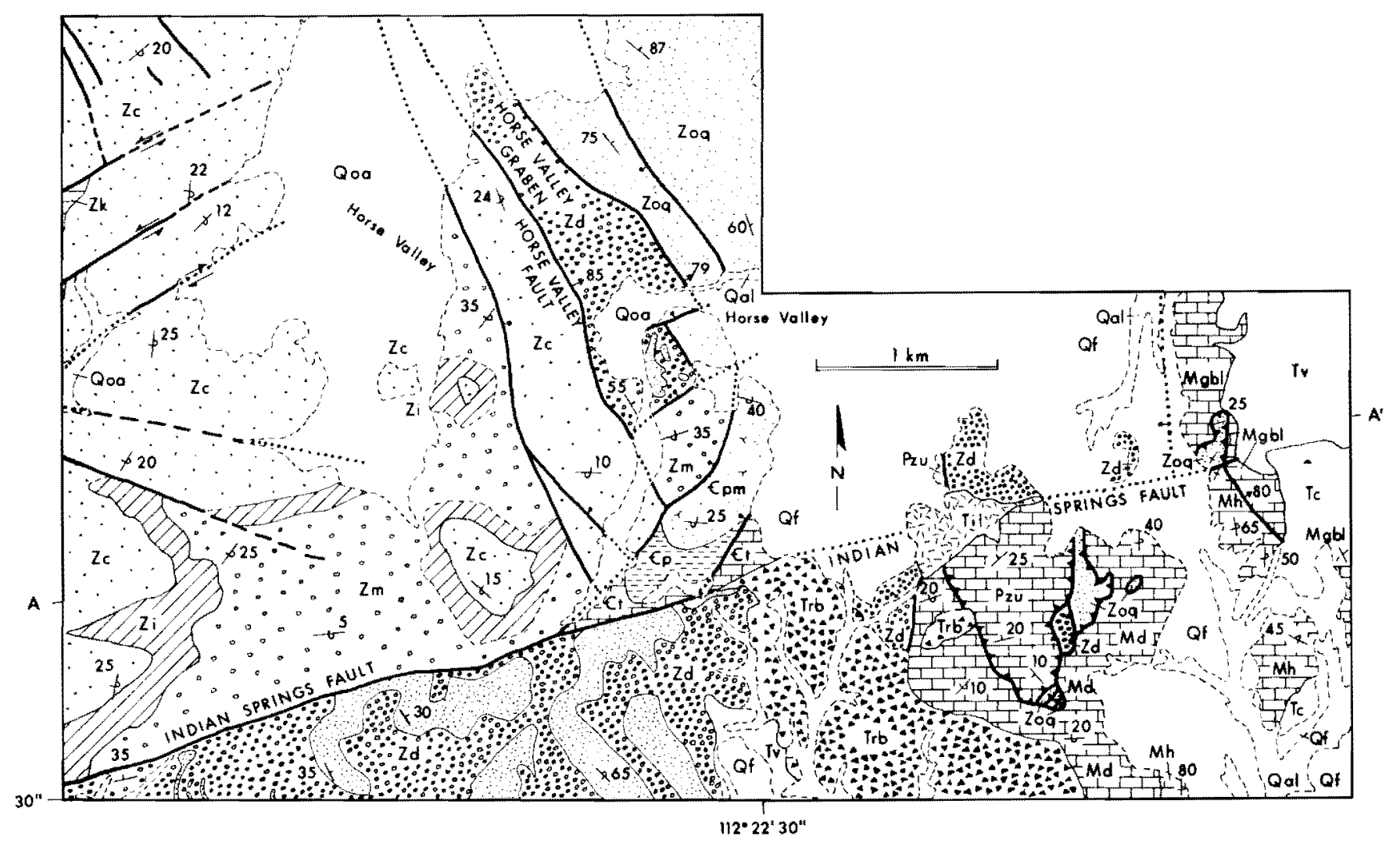

Figure 7. Geologic map of parts of the Dutch Peak and Sabie Mountain Quadrangles (simplified from Morris and Kopf, 1970a, 1970b; Blick, 1979). See Figure 4 for location. Prominent structural features are two klippen of the Sheeprock(?) Thrust, the Indian Springs (tear) Fault and the Horse Valley Graben. Rocks west of the Horse Valley Fault are overturned and in the lower plate of the Pole Canyon Thrust; to the east, rocks are for the most part upright and belong to the upper plate of this thrust. Faults (bold contacts, dashed where approximately located, dotted where concealed): thrust (sawteeth on upper plate); high-angle fault (no ornament; ball on downthrown side; arrows signify inferred lateral slip). Stratigraphic units: Zd, Md, Tc, Tv, Trb, Qf, Qoa, and Qal as in Figure 6; Zoq, upper (quartzite) member of Otts Canyon Formation; Zk, Kelley Canyon Formation; Zc, Caddy Canyon Quartzite; Zi, Inkom Formation; Zm, Mutual(?) Formation; $€$ pm, Prospect Mountain Quartzite; $€ p$, Pioche Shale; $\mathrm{ft}$, Tatow Formation; Mh, Humbug Formation; Mgbl, lower member of Great Blue Formation; $\mathrm{Pzu}$, undifferentiated Paleozoic rocks; Til, intrusive latite porphyry. Cross section $\mathrm{AA}^{\prime}$ is shown in Figure 8.

plate are overturned and dip gently to the west (Figs. 9, 10). Equal-area plots of poles to bedding in the Dutch Peak Formation and Caddy Canyon Quartzite from both plates are illustrated in Figure 11.

Rocks in the lower plate of the thrust are more deformed than those in the upper plate. Pebbles in lower plate conglomerate and diamictite are more strongly flattened, and the Sheeprock Group is correspondingly thinner than in the upper plate (Christie-Blick, 1982). Cleavage and bedding are subparallel beneath the Pole Canyon Thrust, whereas they typically intersect with a large dihedral angle above it (Fig. 11). Cleavage is deformed close to the thrust and therefore predates latest movement on it.

\section{Indian Springs Fault}

The Indian Springs Fault extends east-northeast for more than $8 \mathrm{~km}$ from Cow Hollow to the divide between Horse Valley and Devil Creek (Figs. 3, 4, 7). The fault is close to vertical and its trace is relatively straight. It appears to offset the Sheeprock Thrust (Fig. 7), and thus, contrary to the interpretation of Armstrong (1968), it is not a folded segment of the thrust.

Several additional observations suggest that the Indian Springs Fault is a tear, as proposed by Groff (1959) and Morris and Kopf (1967, 1970a, 1970b). It juxtaposes different facies of the Dutch Peak Formation (Blick, 1979); it 


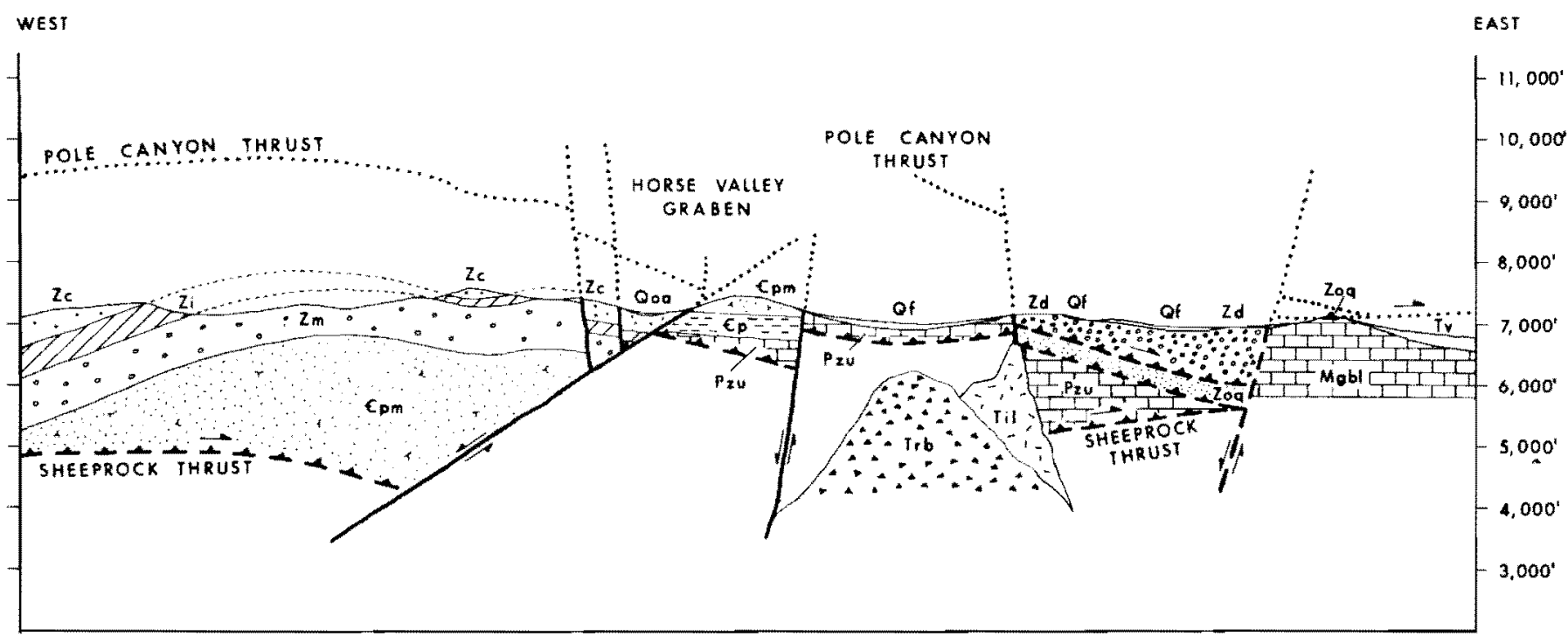

Figure 8. Geologic cross section AA' through parts of the Dutch Peak and Sabie Mountain Quadrangles (located in Fig. 7). Geologic symbols and abbreviations for stratigraphic units as in Figure 7. The Sheeprock Thrust is only approximately located for much of the cross section.

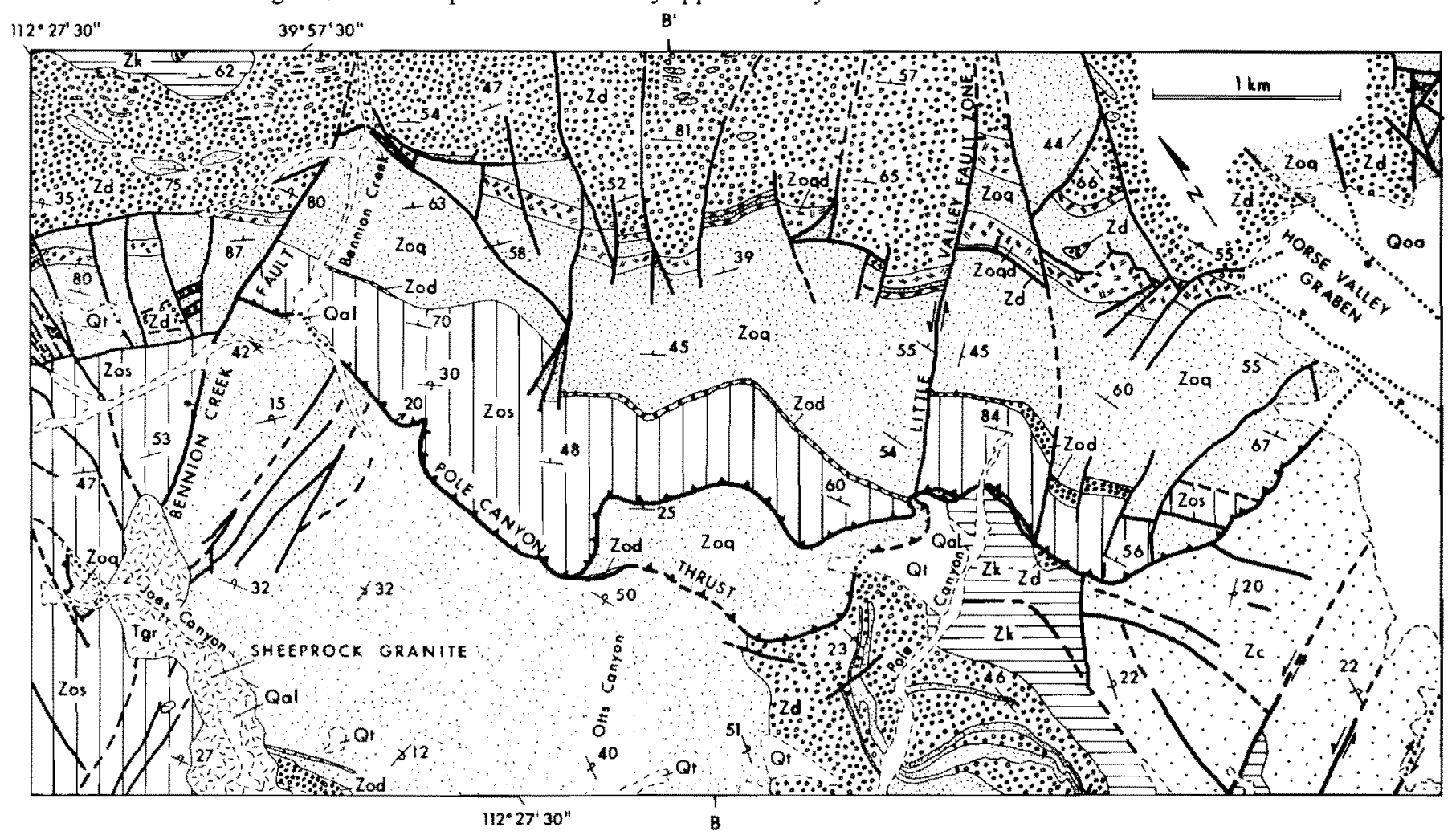

Figure 9. Geologic map of part of the Dutch Peak Quadrangle (simplified from Blick, 1979). See Figure 4 for location. Prominent structural features are the Pole Canyon Thrust, Bennion Creek Fault, Little Valley Fault Zone, and Horse Valley Graben. Fault symbols as in Figure 7. Stratigraphic units: Zos, Zod, Zoq, and Zoqd, lower (slate), middle (diamictite), upper (quartzite) members, and diabase sills of Otts Canyon Formation; Zd, Dutch Peak Formation, with quartzite beds and lenses indicated by stipple pattern; Zk, Kelley Canyon Formation; Zc, Caddy Canyon Quartzite; Tgr, Tertiary granite; Qoa, Qal, and Qt, Quaternary older alluvium, alluvium, and talus. Cross section $\mathrm{BB}^{\prime}$ is shown in Figure 10. 


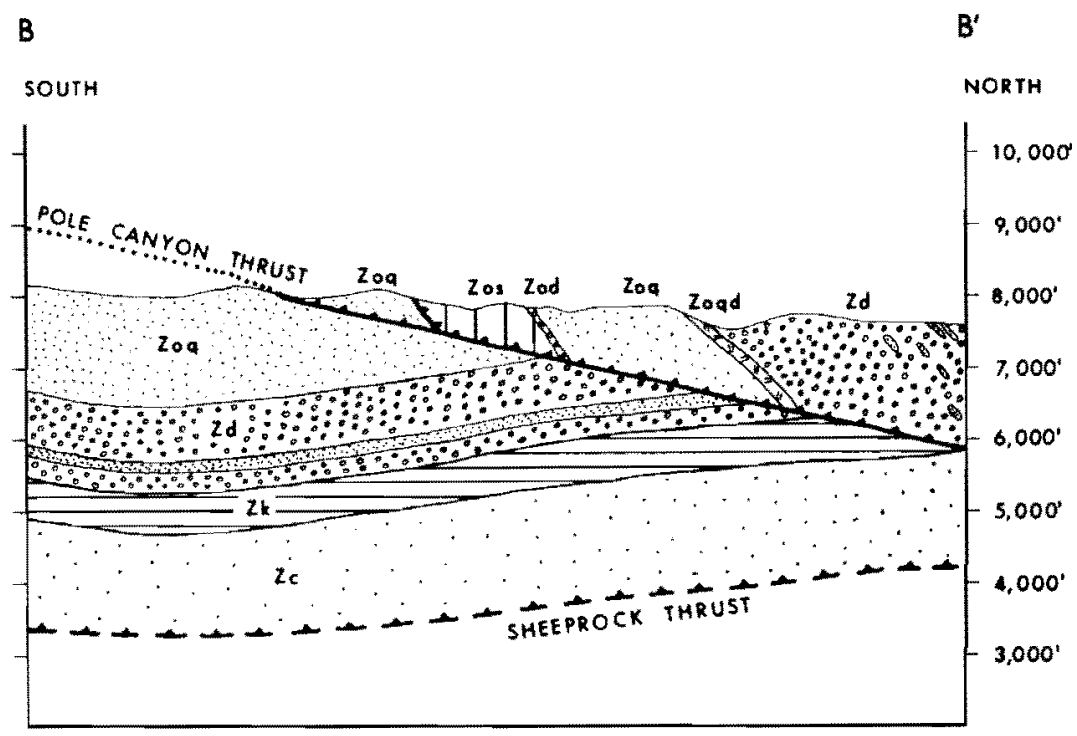

Figure 10. Geologic cross section BB $^{r}$ through part of the Dutch Peak Quadrangle (located in Fig. 9). Geologic symbols and abbreviations for stratigraphic units as in Figure 9.

separates upright beds on the south side from overturned strata on the north side; and slip is thought to have occurred before Basin-Range deformation, because the Indian Springs Fault is cut by igneous rocks of probable Oligocene age (Fig. 7; and Morris and Kopf, 1970a).

\section{Lion Hill Fault and Harker Fault}

Structurally above the Pole Canyon Thrust is a complexly faulted zone cropping out between Harker Canyon and the western flank of the Sheeprock Mountains (Figs. 4, 12). The major feature of this zone is a set of faults that, for the most part, dip at between $10^{\circ}$ and $30^{\circ}$ to the north and northeast and attenuate the stratigraphic section.

The uppermost low-angle fault may be traced continuously from the entrance of Harker Canyon to the entrance of North Oak Brush Canyon, where it is probably truncated by the North Oak Brush Fault (new name; Fig. 12). The normal fault, named the Lion Hill "Thrust" by Cohenour (1959), juxtaposes Lower Cambrian Pioche Shale through Middle Cambrian Marjum Formation above Upper Proterozoic Caddy Canyon Quartzite (Fig. 5), a stratigraphic separation of about 1,500 to $3,500 \mathrm{~m}$. Cohenour (1959) interpreted much of the footwall block as Lower Cambrian Tintic Quartzite (Prospect Mountain Quartzite in this paper), but I have assigned these rocks to the Caddy Canyon Quartzite on the basis of the lithology of interbeds within the quartzite (Christie-Blick, 1982). Rocks of both hanging-wall and footwall blocks dip moderately steeply to the north or northeast (Figs. 12, 13), and beds above the Lion Hill Fault are locally overturned toward the north close to the fault surface.
Beneath the Lion Hill Fault there are at least two other important low-angle fault strands, here together termed the Harker Fault. The Harker fault extends from the entrance of Harker Canyon, where its trace is subparallel to that of the Lion Hill Fault, to the western side of the range (Fig. 12). It cuts only Proterozoic rocks at the present level of exposure and unlike the Lion Hill Fault is offset in several places by cross-faults. The hanging wall of the upper strand consists of lower Caddy Canyon Quartzite east of North Oak Brush Canyon and upper Caddy Canyon Quartzite to the west. The footwall of the lower strand ranges from lower Caddy Canyon Quartzite at the entrance of Harker Canyon, through uppermost Dutch Peak Formation west of North Oak Brush Canyon. The combined stratigraphic separation thus increases from a few hundred metres in the east to more than $1,000 \mathrm{~m}$ in the west. The relative displacement of blocks may be as much as several kilometres because the fault juxtaposes different facies of the Caddy Canyon Quartzite (Blick, 1979). The attitude of bedding in hanging-wall and footwall blocks ranges from subparallel to the Harker Fault or slightly steeper to markedly discordant (Figs. 12, 13).

Both strands of the Harker Fault are offset by the North Oak Brush Fault, which has a stratigraphic separation of at least $2,000 \mathrm{~m}$ in North Oak Brush Canyon, but farther south does not appear to displace contacts within the Sheeprock Group (Fig. 12). This fault is therefore in part older than the Harker Fault or genetically related to it.

\section{Other Faults}

Several other faults are of interest in a consideration of 


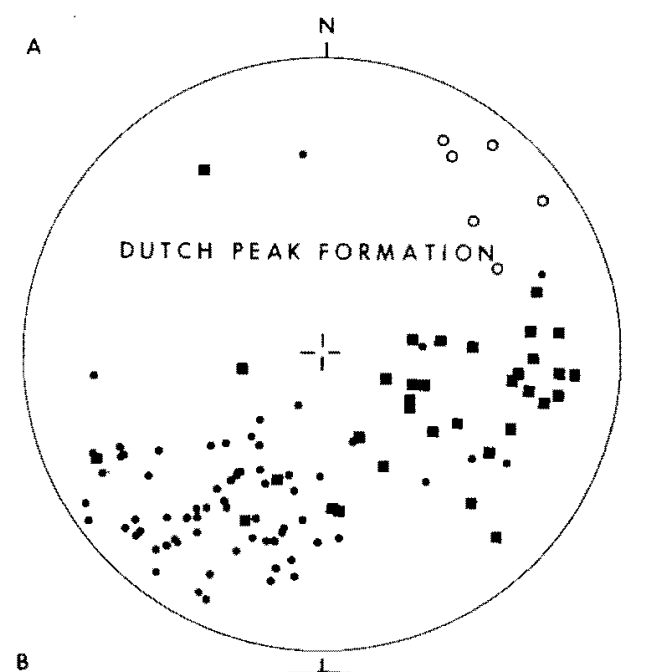

the structural history of the Sheeprock Mountains. The upper plate of the Pole Canyon Thrust is segmented by a set of steeply dipping faults that strike northeast to northnortheast (Figs. 4, 9). Many of these are characterized by left separation. One fault, a strand of the Little Valley Fault Zone (new name), with left separation of about $750 \mathrm{~m}$, clearly terminates against the Pole Canyon Thrust. Several faults with less separation also appear to terminate at the thrust. I conclude that they are tears, active before and/or during movement on the Pole Canyon Thrust. Faults subparallel to the Little Valley Fault Zone, west of and including the Bennion Creek Fault, may also have been initiated as upper plate tears.

The lower plate of the Pole Canyon Thrust is similarly segmented by steeply dipping faults. These strike northeast to east-northeast and are characterized by both right and left separation. However, their significance is uncertain because none of them intersects the thrust.

In the vicinity of Horse Valley four near-vertical faults define what is here named the Horse Valley Graben (Figs. $4,7,9)$. The faults strike north-northwest and terminate against the Little Valley Fault Zone in the north and the Indian Springs Fault in the south. One of the graben faults, the Horse Valley Fault (Morris and Kopf, 1970a, is thought to cut the Pole Canyon Thrust, because it juxtaposes upright beds of the Dutch Peak Formation against overturned Caddy Canyon Quartzite (Fig. 7).

In addition to the Lion Hill and Harker Faults, there is in the upper part of the Harker Canyon a bewildering array of high-angle normal faults that break the rocks into a large number of small blocks (Fig. 12). The faults occur in at least three sets. Some dip to the north, some to the south, and some are approximately vertical and north-striking. Several are cut by the Harker Fault, whereas others offset this fault.

\section{KINEMATIC INTERPRETATION OF MAJOR STRUCTURES}

The Sheeprock Thrust is thought to occur at depth beneath much of the southern Sheeprock Mountains. The Pole Canyon Thrust is interpreted as a structurally higher fault that occurs only north of the Indian Springs Fault. The thrusts probably merge to both east and west. The now-dismembered Pole Canyon Anticline is thought to have developed during propagation of one or both of the thrusts. The recumbent attitude of this fold and the nearhorizontal to eastward dips of the thrusts are explained chiefly by late Cenozoic tilting and propagation of the thrusts from ramps to a flat within the Upper Mississippian

Figure 11. Equal-area, lower hemisphere plots of poles to bedding and cleavage in the Dutch Peak Formation and Caddy Canyon Quartzite. Symbols: dots, poles to upright beds; open circles, poles to overturned beds; squares, poles to cleavage. A. Poles to bedding (73) and cleavage (34), Dutch Peak Formation, upper plate of Pole Canyon Thrust, between Vernon Creek and Harker Canyon. B. Poles to bedding (9) and cleavage (7), Dutch Peak Formation, lower plate of Pole Canyon Thrust in Pole Canyon. C. Poles to bedding (109), Caddy Canyon Quartzite, upper plate

(upright beds) and lower plate (overturned beds) of Pole Canyon Thrust, from approximately the same areas as in $A$ and $B$. See Figures 3 and 4 for locations. 


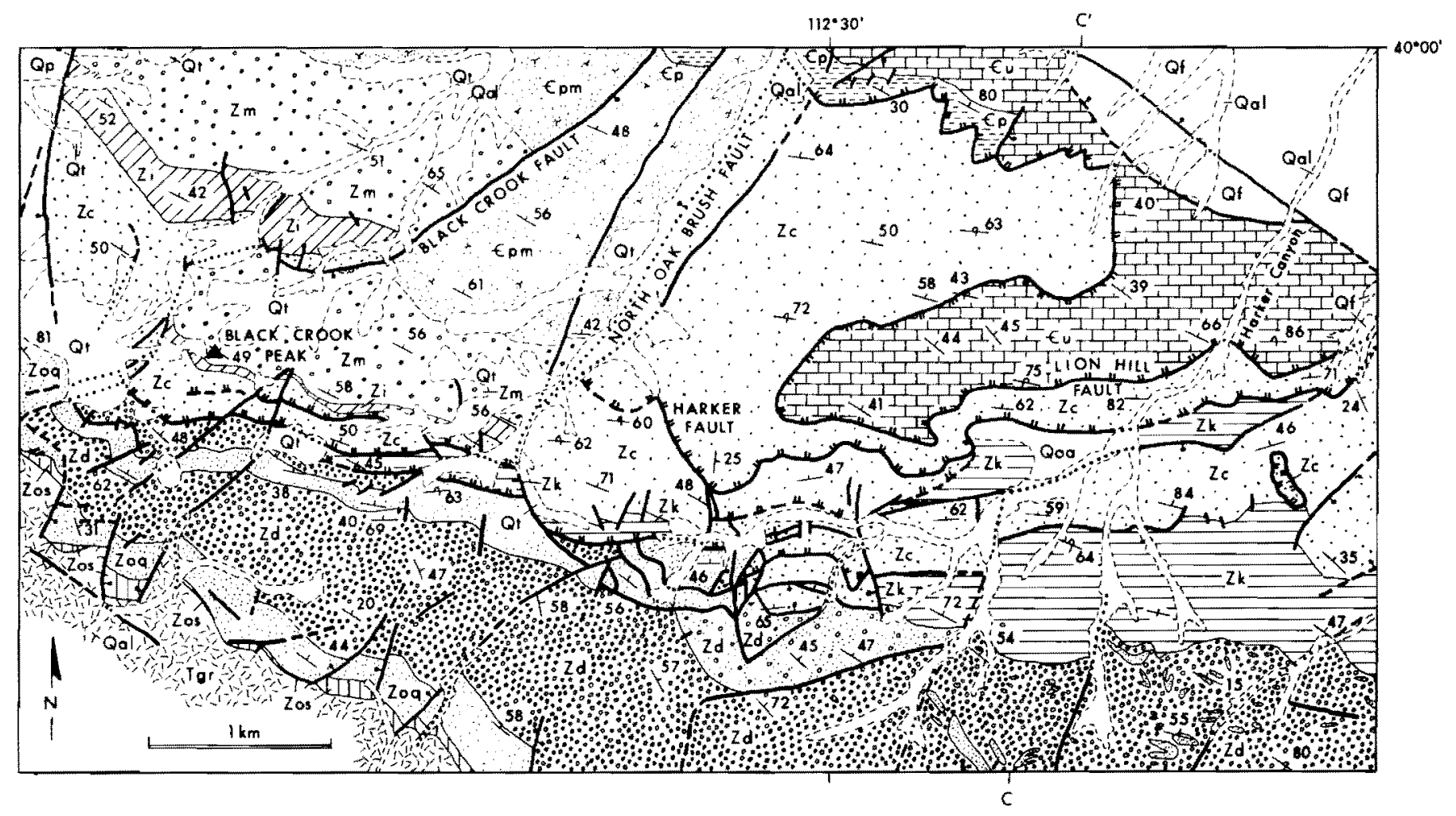

Figure 12. Geologic map of parts of the Dutch Peak and Erickson Knoll Quadrangles (modified from Blick, 1979). See Figure 4 for location. Prominent structural features are the Harker, Lion Hill, Black Crook, and North Oak Brush Faults. Faults (bold contacts, dashed where approximately located; dotted where concealed); low-angle extension fault (double ticks on hanging-wall block); high-angle fault (no ornament; ball on downthrown side). Stratigraphic units: Zos, Zoq, Zd, Zk, and Zc, as in Figure 9, Zi, Inkom Formation; Zm, Mutual(?) Formation; $€ \mathrm{pm}$, Prospect Mountain Quartzite; $€ \mathrm{p}$, Pioche Shale; $€ \mathrm{Cu}$, undifferentiated Cambrian rocks; Tgr, Tertiary granite; Qp, Qf, Qoa, Qal, and Qt, Quaternary pediment gravel, fan gravel, older alluvium, alluvium, and talus. Cross section $\mathrm{CC}^{\prime}$ is shown in Figure 13.

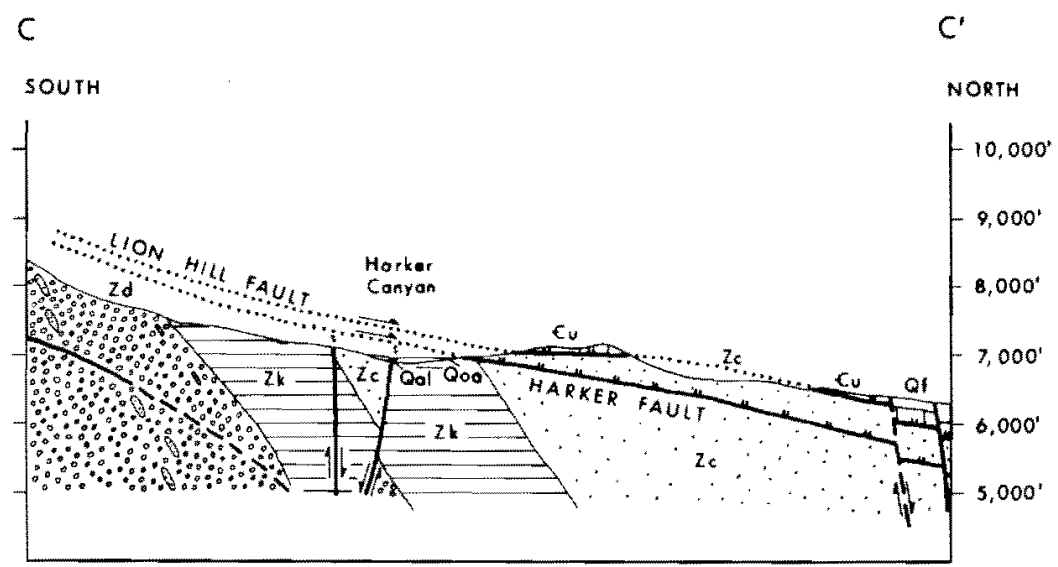

Figure 13. Geologic cross section $\mathrm{CC}^{\prime}$ through part of the Dutch Peak Quadrangle (located in Fig, 12). Geologic symbols and abbreviations for stratigraphic units as in Figure 12. 
section. East-directed tectonic transport, parallel to the Indian Springs Fault ( $075^{\circ}$ azimuth), is corroborated by the vergence of the Pole Canyon Anticline and mesoscopic folds, by the orientation of slickensides on the Pole Canyon Thrust, and by the direction in which the thrusts climb stratigraphically.

The Harker and Lion Hill Faults are interpreted as late Cenozoic extension faults younger than the thrusts, although the possibility of earlier displacement cannot be ruled out. In spite of its reverse separation, the Government Creek Fault of the northern Sheeprock Mountains may also be an extension fault.

\section{Relation Between Sheeprock and Pole Canyon Thrusts}

The geometric relation between the Sheeprock and Pole Canyon Thrusts is uncertain, because they are exposed in different parts of the range and are separated in map view by the Indian Springs Fault (Fig. 4). Two interpretations are possible. In one, favored by Armstrong (1968), the Sheeprock and Pole Canyon Thrusts are considered to be the same fault. In the other interpretation, favored by Morris (1977) and in this paper, the Pole Canyon Thrust is viewed as structurally higher than and subsidiary to the Sheeprock Thrust. In this view the Pole Canyon Thrust is located only north of the Indian Springs Fault, whereas the Sheeprock Thrust occurs on both sides of it. Possible variants of the second interpretation hold that the Pole Canyon and Sheeprock Thrusts merge to the west, or to both east and west. Morris (1977) thought that both thrusts also merge northward with the Tintic Valley Thrust, the trace of which is concealed beneath alluvium of the Tintic Valley, east of the Sheeprock and West Tintic Mountains (Fig. 1).

Critical to the distinction between the two-thrust and single-thrust hypotheses is a comparison of the maximum stratigraphic separation (and probable slip magnitude) of the Pole Canyon Thrust and the separation associated with the small thrust klippe shown in Figure 7 north of the Indian Springs Fault. Stratigraphic separation on the Pole Canyon Thrust probably increases toward the southeast, but is no more than $6 \mathrm{~km}$, or perhaps $4 \mathrm{~km}$ when allowances are made for tectonic flattening beneath the thrust. Assuming that the upper plate was displaced toward the east-northeast (discussed below) and that the offset of formational boundaries in this direction is a measure of the amount of slip, I estimate the slip to be less than $10 \mathrm{~km}$. In comparison, if the klippe is correctly mapped as Otts Canyon Formation faulted above Great Blue Limestone, the stratigraphic separation on that thrust exceeds $10 \mathrm{~km}$, and the slip magnitude is probably considerably greater (at least $16 \mathrm{~km}$, according to Morris, 1977).

In addition, the klippe is only about $3 \mathrm{~km}$ east of the Horse Valley Graben, where overturned rocks in the lower plate of the Pole Canyon Thrust are at least as old as the Caddy Canyon Quartzite, stratigraphically more than $5 \mathrm{~km}$ beneath the Great Blue Limestone (Fig. 5). Even if I have underestimated slip on the Pole Canyon Thrust, it is unlikely that a low-angle thrust could cut up through $5 \mathrm{~km}$ of gently dipping beds in a horizontal distance of $3 \mathrm{~km}$. It is for these reasons that I favor the interpretation of the Pole Canyon and Sheeprock Thrusts as different faults, and interpret the fault beneath the klippe as the Sheeprock Thrust.

In spite of these arguments, there are three circumstances in which the single-thrust hypothesis might still be correct. One arises if the Indian Springs Fault projects or is offset north of the klippe and nearby outcrops of Dutch Peak Formation, which probably occur within the same thrust plate. However, elsewhere the Indian Springs Fault is relatively straight and is not offset by younger faults. A second possibility is that the klippe consists of Caddy Canyon Quartzite or even younger Prospect Mountain Quartzite, rather than Otts Canyon Formation, thus reducing the stratigraphic separation on the thrust. Countering this idea is the close association of the quartzite with Dutch Peak Formation and the fact that Caddy Canyon quartzite does not crop out nearby in the upper plate of the Pole Canyon Thrust. A third possibility is that between the Horse Valley Graben and the klippe the thickness of rocks between the Caddy Canyon Quartzite and Great Blue Formation is substantially less than $5 \mathrm{~km}$ owing to pronounced tectonic flattening.

Where exposed, the Sheeprock Thrust dips gently and probably occurs in the shallow subsurface beneath much of the Dutch Peak Quadrangle. Assuming that the Pole Canyon Thrust is a different fault, there seems to be insufficient vertical space between the thrusts to accommodate a complete upright fold limb beneath the overturned beds (Figs. 7, 8). In Figure 8, I have shown the Pole Canyon and Sheeprock Thrusts merging toward the east to account for the occurrence of the Otts Canyon Formation above the Sheeprock Thrust near location $A^{\prime}$.

\section{Relation Between the Thrusts and Pole Canyon Anticline}

Cohenour (1959) thought that the recumbent Pole Canyon Anticline formed during eastward displacement above the Sheeprock Thrust and that it was subsequently truncated and overridden by the Pole Canyon Thrust plate moving toward the south or southwest. The slip direction of the Pole Canyon Thrust was inferred from "drag and compressional folds observed along the thrust plane" and presumably based, in part, on the prevailing assumption that thrust plates move up-slope.

Working in the Sheeprock Mountains after Cohenour, Harris (1958) recognized the steeply dipping Bennion Creek Fault southwest of its intersection with the Pole Canyon 
Thrust (Fig. 9). He interpreted this segment of the Bennion Creek Fault as a tear and inferred northeastward displacement on the thrust parallel to it. Harris (1958) also suggested a genetic relation between folding and thrusting, although he did not recognize that lower plate rocks are overturned, and he incorrectly concluded that the Pole Canyon Thrust dips to the southwest rather than to the northeast. As a result, Harris's (1958) autochthon (i.e., lower plate) is actually the upper plate of the thrust.

Morris (1977) suggested that the Pole Canyon Thrust developed by dislocation of the limbs of the Pole Canyon Anticline during east-directed displacement above the Sheeprock Thrust. Recently, in a sketch cross section,
H. T. Morris (1982, personal commun.) interpreted the Pole Canyon Anticline as a recumbent fold older than and only indirectly related to the Pole Canyon Thrust, for which he proposed several tens of kilometres of slip. A possible criticism of this idea is that it implies a substantial change in overall crustal shortening across the Indian Springs Fault.

Here I suggest two kinematic interpretations, different from and simpler than that of Morris, but consistent with observations in the Sheeprock Mountains (Fig. 14A) and also with mechanisms of folding and thrust propagation established in well-known fold-thrust belts such as the Canadian Rocky Mountains. In the absence of direct evidence for large slip on the Pole Canyon Thrust, I assume

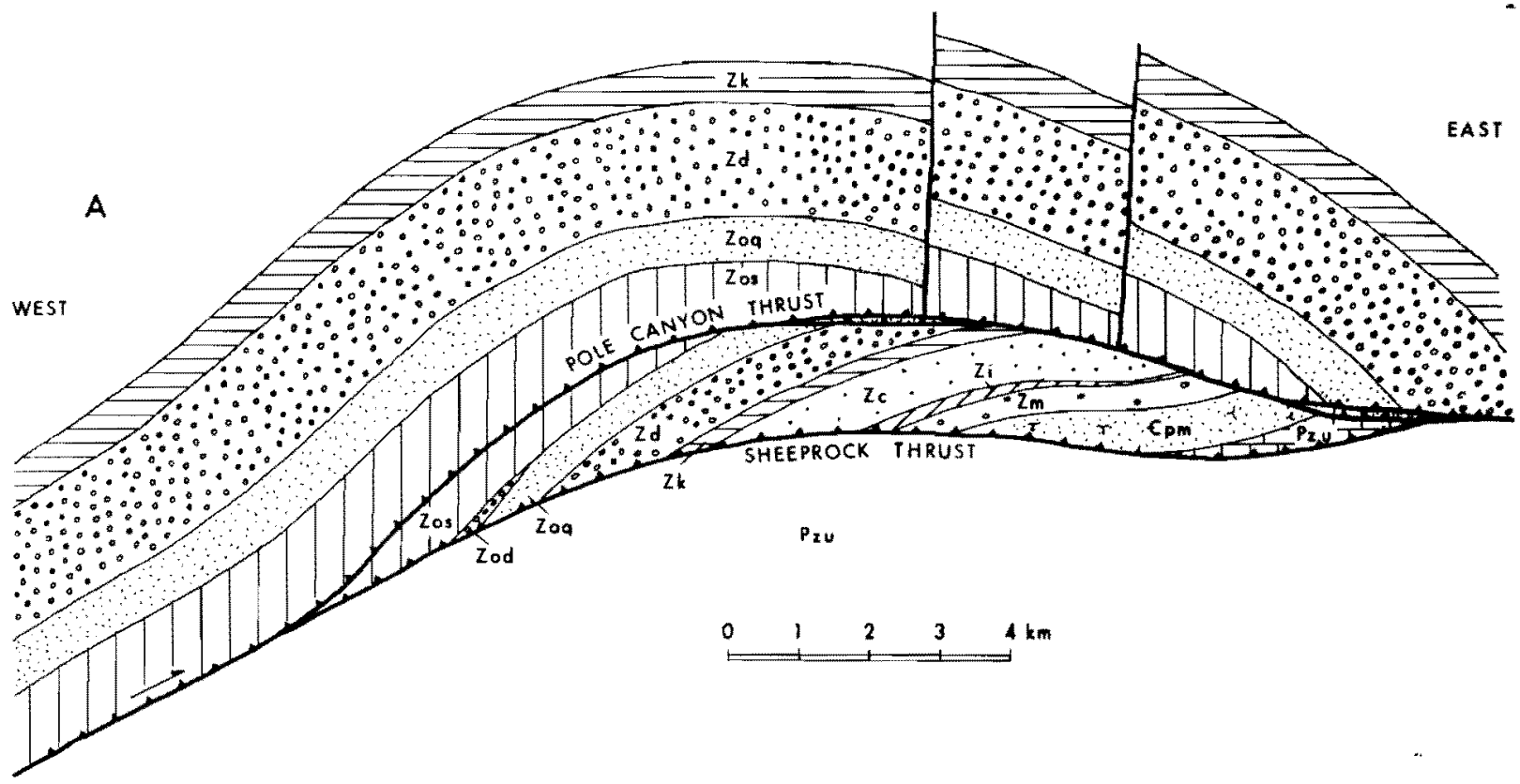

B

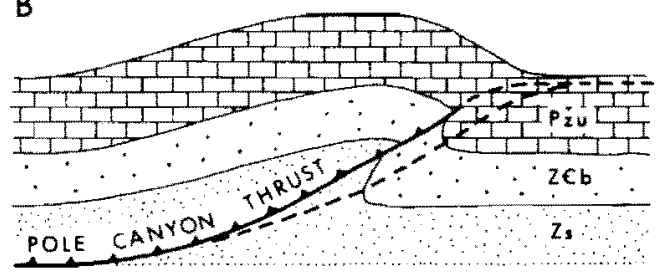

$10 \mathrm{~km}$

Figure 14. A. Conceptual cross section showing the relation between prominent structures in the southern Sheeprock Mountains (Sheeprock and Pole Canyon Thrusts, the recumbent Pole Canyon Anticline and tear faults in the upper plate of Pole Canyon Thrust). Late Cenozoic faults and the hypothetical Skull Valley Thrust (Fig. 1) have been omitted for simplicity. B and C. Proposed origin of the Pole Canyon Anticline as a fault propagation fold related to the Pole Canyon Thrust (B) or Sheeprock Thrust (C). Future thrust traces are shown as dashed lines in each cross section. The present recumbent attitude of the Pole Canyon
C

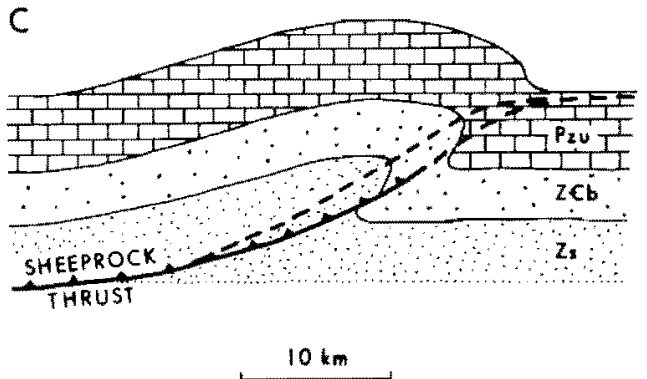

Anticline is explained by a combination of late Cenozoic tilting (see Fig. 16) and propagation of the thrusts from ramps to a flat within the Great Blue Formation (Mississippian). Stratigraphic units: Zos, Zod, and Zoq, lower (slate), middle (diamictite), and upper (quartzite) members of Otts Canyon Formation; Zd, Dutch Peak Formation; Zk, Kelley Canyon Formation; Zc, Caddy Canyon Quartzite; $\mathrm{Zi}$, Inkom Formation; Zm, Mutual (?) Formation; Epm, Prospect Mountain Quartzite; Zs, Sheeprock Group; $Z € b$, Brigham Group; Pzu, undifferentiated Paleozoic rocks. 
the minimum required to explain the observed stratigraphic separation. In addition, I assume that the thrusts and the Pole Canyon Anticline are genetically related.

One possible interpretation, illustrated in Figure I4B, is that the Pole Canyon Anticline was generated by propagation of the Pole Canyon Thrust and that the Sheeprock Thrust is a slightly younger fault which subsequently displaced part of the overturned fold limb. My colleague, T. R. Bultman, has suggested the term "fault propagation fold" for folds generated in this manner. A second possibility (Fig. 14C), which I prefer, is that the Pole Canyon Anticline is a fault propagation fold primarily related to the Sheeprock Thrust and the Pole Canyon Thrust is a minor upper plate imbrication.

The interpretation of the Pole Canyon Anticline as a fault propagation fold is consistent with observed geometry, although not demonstrated conclusively. The limbs of the fold, as they are now juxtaposed, are modeled in Figure 15. In the model, one limb (X) is upright, dipping homoclinally at $50^{\circ}$ toward the northeast. The other limb (Y) is overturned and dips at $20^{\circ}$ toward the west. Figure 11 indicates the degree of scatter of bedding attitudes in the actual fold. The axial surface of the model fold ( $S$ in Fig. 15) is near-horizontal and almost parallel to the Pole Canyon Thrust (T). Note, however, that the geometry of the Pole Canyon Anticline probably changed progressively during deformation as a result of flattening of the overturned limb and displacement on a non-planar fault.

South of the Indian Springs Fault, rocks beneath the Sheeprock Thrust are locally overturned and may constitute the lower limb of a fault propagation fold similar to the Pole Canyon Anticline. In contrast to the region north of the tear, bedding in upper plate rocks is only slightly oblique to the thrust. These rocks may therefore represent the back limb of the proposed fold (compare the left side of Fig. 14A). Such an interpretation is consistent with greater displacement on the Sheeprock Thrust south of the Indian Springs Fault than north of it, where some shortening was accommodated by the Pole Canyon Thrust. Another possibility is that south of the Indian Springs Fault, rocks beneath the Sheeprock Thrust were locally overturned by drag.

\section{Explanation for Present Attitude of Thrusts}

The recumbent attitude of the Pole Canyon Anticline and near-horizontal to eastward dips of the thrusts in the Sheeprock Mountains are anomalous and are thought to be due chiefly to two factors: late Cenozoic tilting and folding above the Sheeprock Thrust where it passed from a ramp to a flat within the Upper Mississippian section. Suppe (1979) has suggested the term "fault-bend folding" for the latter type of deformation.

The magnitude and direction of late Cenozoic tilting

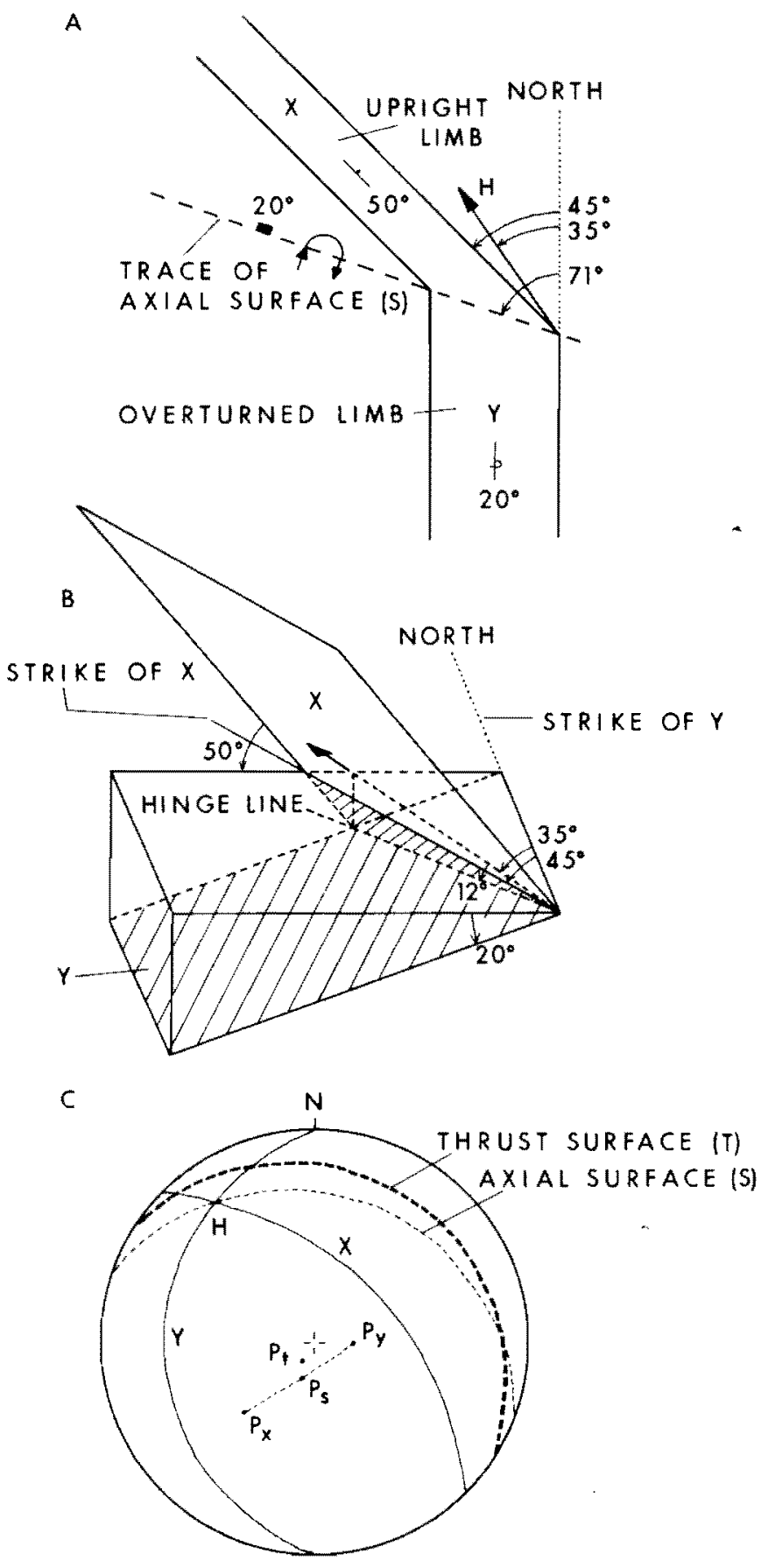

Figure 15. Model of the Pole Canyon Anticline, a prominent recumbent fold, prior to detachment of upright $(X)$ and overturned (Y) limbs by the Pole Canyon Thrust. Bedding attitudes are generalized from the areas shown in Figures 7 and 9. A. Map view. H indicates trend of hinge line. B. Block diagram. C. Equalangle, lower hemisphere plot of surfaces (and poles to surfaces): $\mathrm{X}$ (Px) and $\mathrm{Y}\left(\mathrm{Py}_{\mathrm{y}}\right)$, limbs of Pole Canyon Anticline; S (Ps), axial surface $\left(\right.$ dip $=20^{\circ} \mathrm{N}$, strike $\left.=109^{\circ}\right) ; \mathrm{T}(\mathrm{Pt})$, Pole Canyon Thrust $\left(\right.$ dip $=12^{\circ} \mathrm{N}$, strike $\left.=123^{\circ}\right) . \mathrm{H}$ is hinge line (plunge $=12^{\circ}$, trend $=325^{\circ}$ ). 
are difficult to estimate, because in the Sheeprock Mountains there are no layered rocks that postdate the thrusts and predate Basin-Range extension. The attitude of widespread Oligocene(?) volcanic flows in the adjacent West Tintic Mountains is variable (Morris and Kopf, 1970b) and presumably influenced locally by initial dip, by independent tilting of small blocks, and by associated intrusions. However, away from faults and intrusions, extrusive volcanic rocks, exposed over several square kilometres of the Maple Peak Quadrangle (Fig. 3), dip relatively uniformly toward the northeast at about $25^{\circ}$. This direction of tilting is consistent, perhaps fortuitously, with the northward to eastward dips of the Proterozoic and Paleozoic rocks in much of the Sheeprock Mountains. However, the magnitude of tilting is reasonable when compared with that observed elsewhere in the Basin-Range province of Utah and Nevada. Regionally, range tilts average $15^{\circ}$ to $20^{\circ}$, and few initially horizontal Cenozoic rocks in Utah and Nevada dip at more than $32^{\circ}$ (Stewart, 1980). For these reasons, I tentatively estimate late Cenozoic tilting of the Sheeprock Mountains to have been about $25^{\circ}$ toward the northeast. Although the evidence is admittedly weak and the direction of tilt may be revised by future observations, the magnitude of tilt is unlikely to be substantially more than $25^{\circ}$ and may be considerably less.

For want of a better value, the estimated tilt has been used in Figure 16 to correct the attitudes of the Pole Canyon Thrust and bedding depicted in Figure 15. The corrected attitude of the Pole Canyon Thrust ( $13^{\circ}$ dip to the southwest) is still near horizontal. If the Pole Canyon Anticline is a fault propagation fold, it is likely that segments of the associated thrusts originally dipped more steeply to the southwest or west. In the Maple Peak Quadrangle, the Sheeprock Thrust is preferentially located within the upper and Chiulos (shale) Members of the Mississippian Great Blue Formation (Morris and Kopf, 1970b; and Fig. 6). I therefore propose that the upper plate of the Sheeprock Thrust (including the Pole Canyon Anticline and Thrust north of the Indian Springs Fault) was folded during displacement over a bend in the fault where it passed from a ramp in much of the Proterozoic and Paleozoic section to a flat within the Upper Mississippian carbonate and shale section (Fig. 14). Fault-bend folding may also be associated with ramps in structurally lower faults such as the Tintic Valley Thrust, although this has not yet been documented.

\section{Direction of Slip on Pole Canyon and Sheeprock Thrusts}

Evidence for the direction of tectonic transport associated with the Pole Canyon Thrust and Anticline is summarized in Table 1. If the Indian Springs Fault is a major tear as I and others have supposed, it is reasonable to infer tectonic transport parallel to it $\left(075^{\circ}\right.$ azimuth). This is cor-

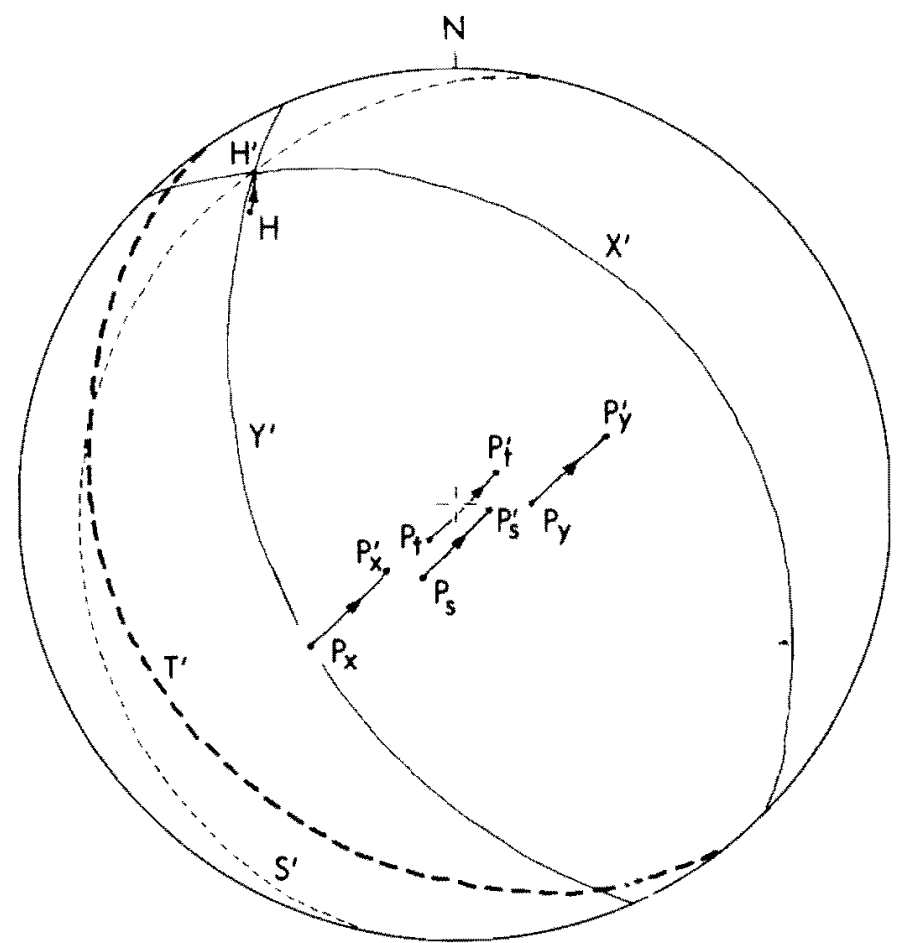

Figure 16. The attitudes of fold limbs ( $\mathrm{Px}$ and $\mathrm{Py}$ ), axial surface (Ps), Pole Canyon Thrust (Pt), and hinge line (H) from Figure 15 corrected for late Cenozoic tilting, estimated as $25^{\circ}$ toward the northeast: $X^{\prime}\left(P^{\prime} x\right)$, dip $=25^{\circ} \mathrm{NE}$, strike $=135^{\circ} ; Y^{\prime}\left(P^{\prime} y\right)$, dip $=$ $42^{\circ} \mathrm{W}$ overturned, strike $=156^{\circ} ; \mathrm{S}^{\prime}\left(\mathrm{P}^{\prime} \mathrm{s}\right)$, dip $=9^{\circ} \mathrm{W}$, strike $=013^{\circ}$; $T^{\prime}\left(\mathrm{Pt}^{\prime}\right) \operatorname{dip}=13^{\circ} \mathrm{W}$, strike $=143^{\circ} ; \mathrm{H}^{\prime}$, plunge $=7^{\circ}$, trend $=329^{\circ}$.

roborated by the direction of vergence of the Pole Canyon Anticline (Figs. 15, 16), by a separation arc plot (Hansen, 197I) of 20 asymmetrical folds in the upper plate, close to the thrust (Fig. 17), and by the trend of slickensides on several square metres of thrust surface on the ridge south of Bennion Creek (located in Fig. 9). Azimuths are not significantly changed by a correction for late Cenozoic tilting of the Sheeprock Mountains.

TABLE 1. EVIDENCE FOR THE DIRECTION OF TECTONIC TRANSPORT ASSOCIATED WITH THE POLE CANYON THWUST ANO ANTICLINE

Azimuth

Indian Springs tear faute (strike; Fig. 7) $075^{\circ}$

Modeled recumbent Pole Canyon antic 1 ine

(normal to fold axis trend; Figs. 15, 16) $0550\left(059^{\circ}\right)$

Separation are plot of asymetrical folds

(bisector of separation angle; Fig. 17)

$086^{\circ} \pm 43^{\circ}$

slickensides on Pole Canyon thrust (trend)

$0690(0700)$

upoer plate tear fauls (strike; Fig. 9)

$-0370$

Lower plate tear (?) fallts (strike; Fig. 7)

$\sim 060^{\circ}$

Note: correction for late Cenozolc tilting of the Sheeprock Mountains changes the azinuths givers by less than $5^{\circ}$ (values in parentheses). 


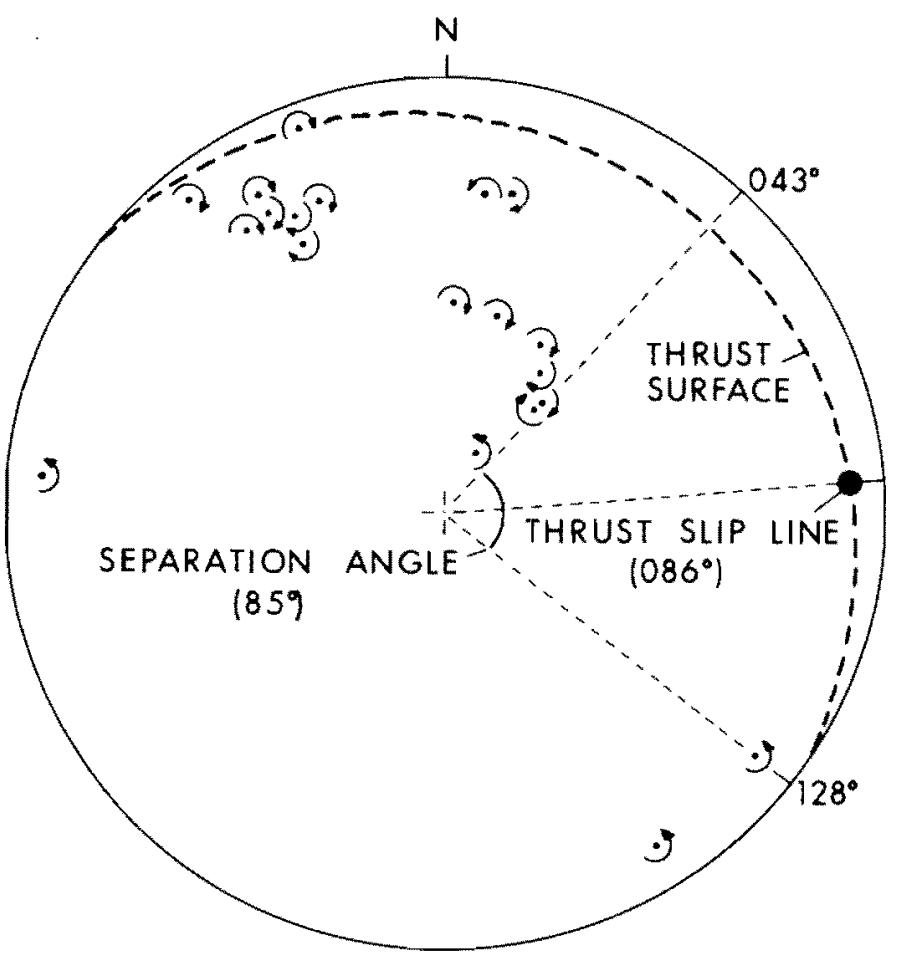

Figure 17. Equal-area, lower hemisphere separation arc plot of 20 minor asymmetrical folds in the lower member of the Otts Canyon Formation, in the upper plate of the Pole Canyon Thrust, close to the thrust surface. Fold axes are indicated by dots. Clockwise arrows signify $Z$-folds and counterclockwise arrows, S-folds. Separation angle $=85^{\circ}$, measured in a horizontal plane. Inferred slip line of Pole Canyon Thrust is approximately $086^{\circ}$. Note that a great circle approximating the fold-axis distribution is inclined to the Pole Canyon Thrust.

It is not clear why minor upper plate tear faults (average strike, $037^{\circ}$ ) are oblique to the Indian Springs Fault. Three possible explanations are that (1) they represent longitudinal shortening parallel to the axis of the Pole Canyon Anticline (but see Dahlstrom, 1970), (2) the Pole Canyon Thrust experienced an earlier phase of northeastward displacement, and (3) the tear faults originated parallel to the Indian Springs Fault and assumed their present orientation through counterclockwise rotation.

Eastward displacement on the Sheeprock Thrust, parallel to the Indian Springs Fault, is consistent with the direction in which the thrust climbs stratigraphically and the sense of overturning of beds beneath the thrust.

The inferred direction of tectonic transport in the Sheeprock Mountains is also consistent with regional geologic relationships (Armstrong, 1968). In particular, the Indian Springs Fault is approximately parallel to inferred tear faults in the adjacent East Tintic Mountains (located in Fig. 1) and in the Gilson Mountains at the southern end of the Tintic Valley $\left(055^{\circ}\right.$ to $065^{\circ}$ azimuth; Morris and Shepard, 1964; Roberts and others, 1965; Morris, 1977).

\section{Sense of Slip on Indian Springs Fault}

Groff (1959) inferred left slip on the Indian Springs Fault based on left separation of juxtaposed Proterozoic rocks. However, separation is a poor indicator because beds are overturned to the north but not to the south and because the Dutch Peak Formation changes facies across the fault (Blick, 1979). Morris and Kopf (1970a) and Morris (1977) indicated right slip, presumably on the assumption that the Pole Canyon Thrust and Anticline were responsible for additional shortening in the Sheeprock Thrust plate north of the tear.

In my opinion, the sense of slip on the Indian Springs Fault is probably variable, depending on structural position and on any changes in crustal shortening across it. For example, assuming equivalent overall shortening on each side of the fault, right slip would be favored between rocks above the Sheeprock Thrust on the north side and lower plate rocks to the south (and vice versa). Segments of the tear which juxtapose upper plate rocks that are overturned on the north side but upright to the south would be characterized by left slip.

\section{Relation Between Thrusts and Low-Angle Normal Faults}

Fault geometry in Harker Canyon (Figs. 3, 12, 18) sug-

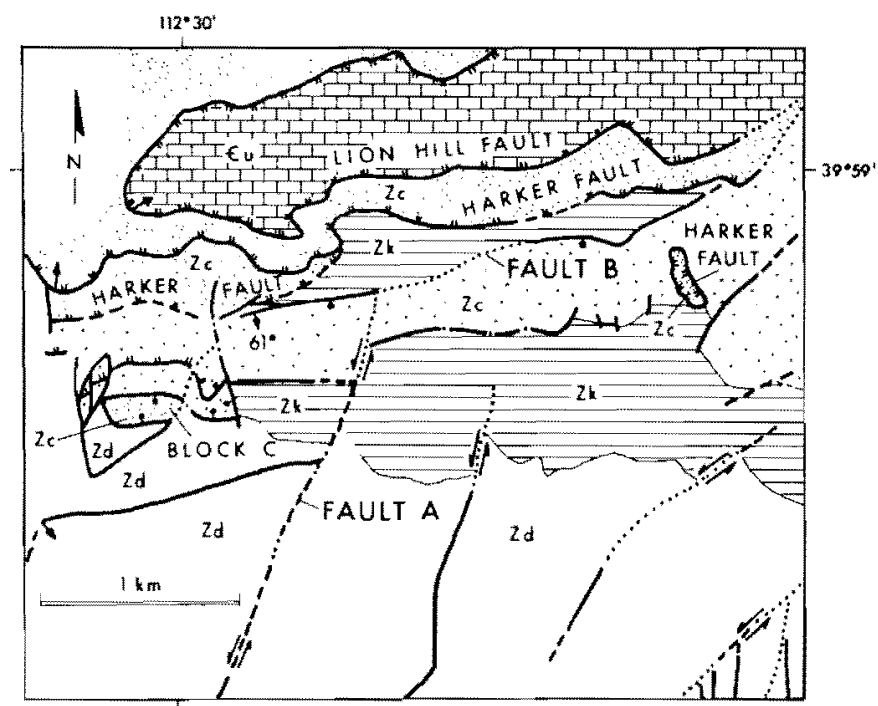

Figure 18. Simplified fault map of the central part of Harker Canyon abstracted from Figure 12. (See Fig. 12 for explanation of symbols.) Fault A probably originated as a tear fault and terminates against normal fault $B$. Fault $B$ is truncated by the Harker Fault (see also cross section in Fig. 13). Latest movement on the Harker Fault is therefore thought to postdate the Pole Canyon Thrust. The Harker Fault is also cut by younger normal faults. For example, based on a comparison of facies of the Caddy Canyon Quartzite ( $\mathrm{Zc}$ ), block $\mathrm{C}$ belongs in the hanging-wall block of the Harker Fault (dense stipple pattern). The Caddy Canyon Quartzite of the footwall block is indicated by a sparse stipple pattern. 
gests that latest movement on the Harker and Lion Hill Faults postdates the Sheeprock and Pole Canyon Thrusts. Fault $\mathrm{A}$ in Figure 18 probably originated as a tear, because it parallels tear faults in the upper plate of the Pole Canyon Thrust and, like them, displays left separation. However, the following argument holds even if it is younger than the thrusts. It terminates against normal fault $B$, which dips steeply to the south and juxtaposes lower Caddy Canyon Quartzite against Kelley Canyon Formation. Fault B is clearly truncated by the north-dipping Harker Fault in the eastern part of Harker Canyon (Figs. 12, 13, 18). The Harker Fault is thus thought to be younger than the Pole Canyon Thrust.

The slip direction of the Harker and Lion Hill Faults is not well constrained, but the vergence of a few asymmetrical folds close to the faults suggests movement to the north or northeast. This tentative slip direction, transverse to that inferred for the thrusts, is consistent with a different age of deformation, but it poses a geometrical problem.

In Harker Canyon, the Harker and Lion Hill Faults dip to between north and northeast less steeply than bedding in juxtaposed rocks (Fig. 13), and northward slip should therefore have led to stratigraphic repetition, not to the observed attenuation (e.g., Fig. 2A, 2C). At least two kinds of explanation are possible. One is that stratigraphic omission was achieved by a component of slip to the southwest during an earlier phase of deformation. In this view, the Harker and Lion Hill Faults are (1) back-thrusts (analogous to Fig. 2F); or (2) expressions of extension in the hinterland of the advancing thrust wedge; or (3) extension faults either older than or younger than the thrusts, but active before Basin-Range block-faulting and tilting. The back-thrust explanation is geometrically possible but mechanically unlikely, because thrust faults do not ordinarily propagate down-section (Dahlstrom, 1970). Explanations invoking earlier extension are discussed below in the context of regional geology. However, local evidence against any postulated slip to the southwest is that there is no support for such a slip direction in minor structures close to the faults.

My preferred explanation for stratigraphic omission on the Harker and Lion Hill Faults involves prior displacement on a hypothetical high-angle (normal?) fault or faults located south or southwest of the Sheeprock Mountains, and requires movement on the low-angle faults only toward the north or northeast, down the present dip. The hypothesis is illustrated with reference to the Lion Hill Fault by means of a sketch cross section in Figure 19, and a similar scenario could be envisaged for the Harker Fault. Locally, the Harker Fault is parallel to bedding in the Kelley Canyon Formation (shale), the oldest unit exposed in the hanging-wall block. The oldest beds exposed above the Lion Hill Fault belong to the Pioche Shale. Thus, the Harker and Lion Hill Faults may have originated as

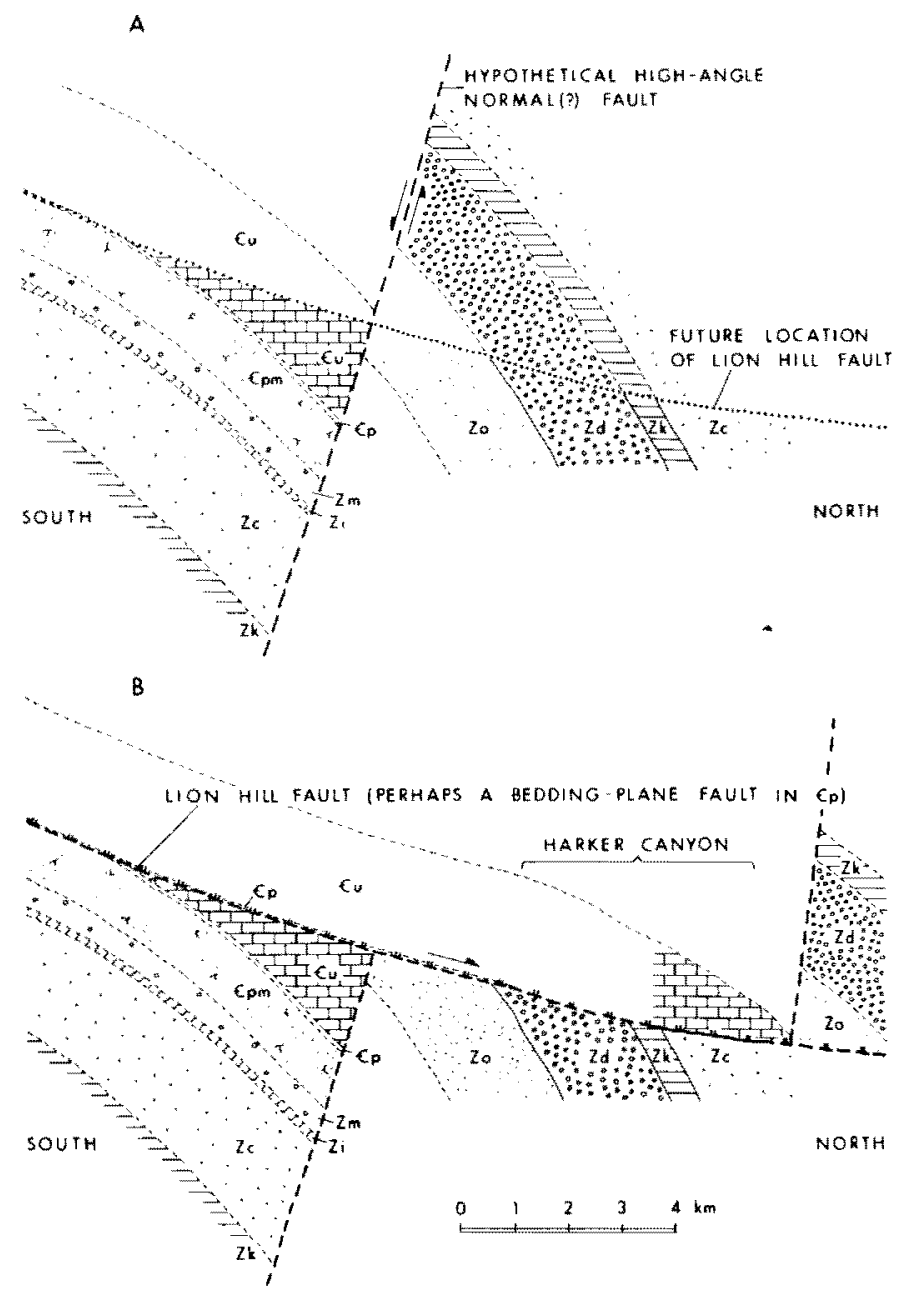

Figure 19. Explanation for stratigraphic omission on the Lion Hill Fault. Large normal separation is first achieved on a hypothetical high-angle fault (or faults) south or southwest of the Sheeprock Mountains (A). Subsequently, hanging-wall and footwall blocks are juxtaposed by northward displacement on the Lion Hill Fault (B). The cross sections are approximately to scale, but only conceptual (solid lines indicate parts constrained by observation). The high-angle fault may be listric at depth. The interpretation of the Lion Hill Fault as a bedding-plane fault in the Pioche Shale ( $\mathrm{Cp}$ ) is not a necessary aspect of the model. Other stratigraphic units: Zo, Otts Canyon Formation; Zd, Dutch Peak Formation; Zk, Kelley Canyon Formation; Zc, Caddy Canyon Quartzite; Zi, Inkom Formation; Zm, Mutual (?) Formation; $6 \mathrm{pm}$, Prospect Mountain Quartzite; $€ \mathrm{Cu}$, undifferentiated Cambrian rocks.

bedding-plane faults within these incompetent formations, although such an origin is not a necessary aspect of the hypothesis.

Three implications of the hypothesis are that (1) the Harker and Lion Hill Faults were active primarily after pronounced block-faulting, consistent with a late Cenozoic age; (2) the stratigraphic units cut out by the low-angle faults occur in the hanging-wall blocks of these faults beneath the valley fill north of the Sheeprock Mountains; and (3) high-angle faults with large separation terminate against 
the low-angle faults in both hanging-wall and footwall blocks. The North Oak Brush Fault and Black Crook Fault (Fig. 12) and fault B in Figure 18 may be examples of such faults, although the first two were reactivated after displacement by the Harker Fault. The second and third implications cited above suggest possible tests of this model through deep drilling and the acquisition of seismic reflection profiles for the region north of the Sheeprock Mountains.

A significant problem evident in Figure 19 is the magnitude of slip indicated on the postulated high-angle fault(s) (about $10 \mathrm{~km}$ ), although the slip could be reduced using different geometric assumptions. It is also conceivable, if unlikely, that rocks in the hanging-wall block of the Lion Hill Fault were derived from south of the Indian Springs Fault or from the lower plate of the Sheeprock Thrust.

\section{Government Creek Fault}

The Government Creek Fault (Cohenour, 1959) occurs north of the area on which this paper is primarily focused (Fig. 1), but it is of interest because it is approximately parallel to the Harker and Lion Hill Faults and may be a related structure.

Figure 20 is a cross section through the Government Creek Fault, modified from section DD' of Cohenour (1959). The fault dips to the north at $20^{\circ}$ to $25^{\circ}$ and juxtaposes rocks as old as the Caddy Canyon Quartzite above the Middle Cambrian Marjum Formation. Hanging-wall and footwall rocks both dip to the north at about $45^{\circ}$.

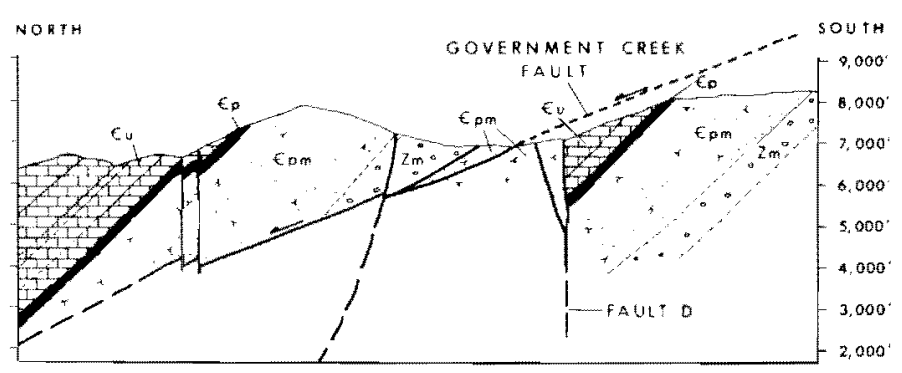

Figure 20. Geologic cross section through the Government Creek Fault (modified from cross section DD' of Cohenour, 1959). According to Cohenour, fault $D$ terminates against the Government Creek Fault, which is therefore interpreted by me to be younger. Stratigraphic units: Zm, $€ \mathrm{pm}, € \mathrm{p}$ and $€ \mathrm{Cu}$, as in Figure 19.

Cohenour (1959) thought the Government Creek Fault was a strike-slip fault, associated with the Pole Canyon and Lion Hill "Thrusts." However, 1 propose an alternative interpretation, that it is a Cenozoic extension fault geometrically analogous to the one shown in Figure $2 \mathrm{~A}$ and $2 \mathrm{C}$. Cohenour's (1959) geologic map indicates that fault $\mathrm{D}$ in Figure 20 terminates against the Government Creek Fault in the same way as fault B (Fig. 18) terminates against the Harker Fault. The segment of fault D inferred to be displaced by the Government Creek Fault is not exposed in the hanging-wall block because another low-angle fault intervenes.

\section{AGE OF DEFORMATION}

The timing of deformation is poorly constrained in the Sheeprock Mountains but may be summarized as follows if my preferred interpretations are assumed.

The Sheeprock and Pole Canyon Thrusts and the Indian Springs (tear) Fault deformed Pennsylvanian rocks and are cut by igneous rocks of probable Oligocene to Miocene age. Basin-Range extension, between Miocene and present time, produced both high-angle faults (e.g., the North Oak Brush Fault, the Horse Valley Graben, and range-bounding faults) and low-angle ones (e.g., the Harker, Lion Hill, and Government Creek Faults). Some Mesozoic (tear?) faults, such as the Bennion Creek Fault, were reactivated, possibly during mid- to late Cenozoic time. However, all activity on the Bennion Creek Fault predates intrusion of the Early Miocene Sheeprock Granite.

Regional arguments suggest additional constraints on the age of the Sheeprock and Pole Canyon Thrusts. Stratigraphic evidence in central Utah indicates major orogenic activity during Late Cretaceous time, deformation beginning in latest Jurassic or Early Cretaceous time (Armstrong, 1968; Burchfiel and Hickcox, 1972; Crittenden, 1976). In several well-studied parts of the Cordilleran foldthrust belt, there is a tendency for the principal thrusts to initiate sequentially in the direction of tectonic transport. Examples are in the Canadian Rocky Mountains (Dahlstrom, 1970; Price, 1981), Wyoming and Idaho (Armstrong and Oriel, 1965; Oriel and Armstrong, 1966; Royse and others, 1975), and in southern South America (Winslow, 1981). With the possible exception of the hypothetical Skull Valley Thrust (Fig. 1), the Sheeprock and Pole Canyon Thrusts are the westernmost thrusts in the foreland belt at the latitude of the Sheeprock Mountains (Fig. 21). The Sheeprock and Pole Canyon Thrusts are therefore likely to be of latest Jurassic to Early Cretaceous age, as proposed by Armstrong (1968).

\section{REGIONAL SIGNIFICANCE OF LOW-ANGLE FAULTS IN SHEEPROCK MOUNTAINS}

The relative ages and significance of low-angle faults in the Basin-Range province continue to be controversial. Available evidence suggests that the thrusts are for the most part older than and unrelated to low-angle extension faults, and my preferred interpretation of the structure of the Sheeprock Mountains is consistent with this view. However, because there is still no consensus, it is worth reviewing the spectrum of possible interpretations.

Thrusts in the Cordilleran fold-thrust belt of Utah, 


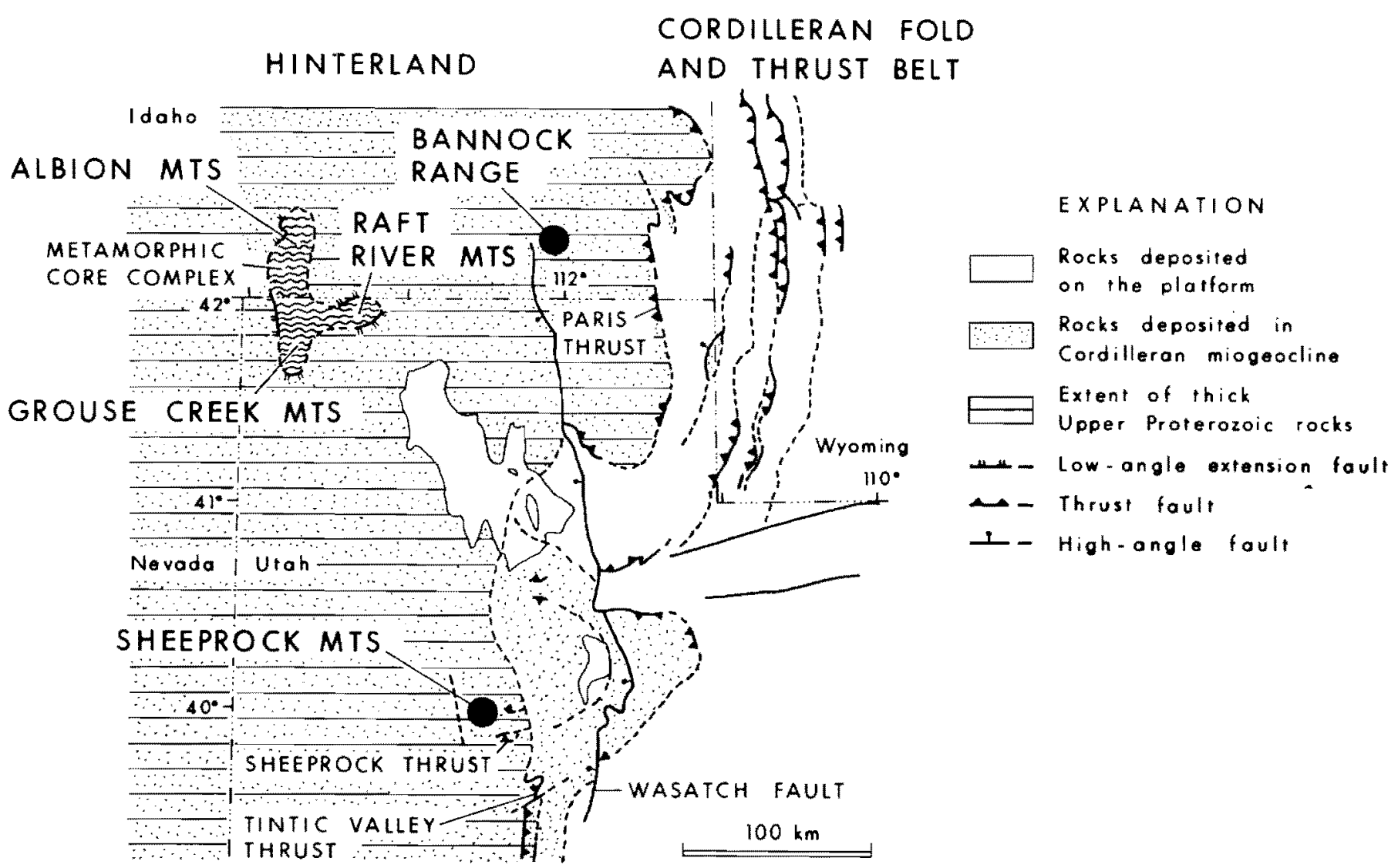

Figure 21. Simplified map of the Cordilleran fold and thrust belt and hinterland in northern Utah and adjacent Idaho and Wyoming (modified from Crittenden, 1976; Allmendinger and Jordan, 1981). Filled circles indicate location of extension faults, discussed in the text, in the southern Bannock Range and Sheeprock Mountains.

Idaho, and Wyoming range in age from Late Jurassic to earliest Eocene (Armstrong and Oriel, 1965; Oriel and Armstrong, 1966; Armstrong, 1968). In contrast, low angle extension faults of the hinterland are thought to be mainly middle to late Cenozoic structures for two reasons. First, many of the extension faults juxtapose rocks of very different metamorphic facies in regions such as the Raft River and Grouse Creek Mountains (Fig. 21), where metamorphism is known to have persisted until latest Oligocene time (Compton and others, 1977; Compton and Todd, 1979). In that area, the horizontal separation of high-grade rocks suggests as much as $30 \mathrm{~km}$ of eastward transport after metamorphism. In addition, geobarometry suggests that metamorphism occurred at depths of perhaps 10 to $20 \mathrm{~km}$ (Wernicke, 1982), thus limiting the amount of earlier tectonic denudation. A second reason for inferring that the extension faults are predominantly Cenozoic is that there is no evidence for significant surface faulting prior to the deposition of Eocene-Oligocene volcanic and sedimentary rocks, because Cenozoic rocks consistently overlie relatively undeformed and unmetamorphosed Upper Paleozoic beds (Armstrong, 1972; Wernicke, 1982). Many workers thus now regard low-angle faults of the so-called metamorphic core complexes south of the Snake River Plain for the most part as only slightly older than the Miocene to Holocene Basin-Range faults (Crittenden, 1980). The flatlying detachment into which the latter are presumed to merge is viewed as structurally lower than detachments associated with the metamorphic core complexes.

However, some pre-Cenozoic extension in the metamorphic terranes is not precluded, and some (older-overyounger) faults may be thrusts rather than extension faults. Available dates suggest that metamorphism, igneous activity, and associated deformation were widespread although possibly sporadic in the hinterland during Jurassic and Cretaceous times (summarized by Allmendinger and Jordan, 1981). For example, premetamorphic to synmetamorphic ductile low-angle faults in the Albion Mountains (Fig. 21) may be as old as Jurassic and thus predate the foreland thrusts (Miller, 1980). In addition, although pure gravity gliding models for the foreland thrusts (e.g., Hose and Danes, 1973) are untenable (Armstrong, 1972), some workers continue to interpret the principal hinterland extension faults as reactivated Mesozoic structures (Crit- 
tenden, 1979; Allmendinger and Jordan, 1981). Allmendinger and Jordan (1981) attributed some of the observed stratigraphic omission to translation of the foreland thrust wedge over independent thermal domes.

In view of the regional evidence for significant Cenozoic extension before the development of the present Basin-Range topography and the possibility that some hinterland extension may have occurred still earlier before or during thrusting, 1 here reconsider the possibility of pre-late Cenozoic movement on the Harker and Lion Hill Faults of the Sheeprock Mountains. Assuming that the Sheeprock Mountains tilted about $25^{\circ}$ to the northeast during late Cenozoic time, these faults, if they existed, would have been near-horizontal in mid-Cenozoic time and southwestto west-dipping in Jurassic time. Such attitudes would have permitted a component of movement toward the southwest during earlier extensional events (see Fig. 2D, 2E). On the other hand, the suggestion of substantial Mesozoic extension in the Sheeprock area is arguably at odds with the apparent lack of corresponding surface faulting elsewhere in the hinterland (e.g., Wernicke, 1982). Significant Cretaceous extension is particularly unlikely if the fold-thrust belt is primarily a response to regional horizontal compression (e.g., Burchfiel and Davis, 1975; Chapple, 1978; Price, 1981). The possibility of appreciable mid-Cenozoic movement on the Harker and Lion Hill Faults is perhaps more defensible if not demonstrable.

These deliberations about extension faults in the Sheeprock Mountains bear on the interpretation of similar structures in the southern Bannock Range of southeastern Idaho (Fig. 21). That range occurs west of the trace of the Paris Thrust, and like the Sheeprock Mountains it occupies a transitional position between the fold-thrust belt and the hinterland. In the Bannock Range, Oriel and Platt (1979) and Link (1980, 1981, 1982) have recognized three major lithologically distinct "thrust plates" separated by lowangle normal faults. The lowermost plate consists of the Scout Mountain (diamictite) and Bannock Volcanic Members of the Pocatello Formation (equivalent to the Dutch Peak Formation of the Sheeprock Mountains; ChristieBlick, 1982), the middle plate consists of quartzite rocks of the Brigham Group, and the upper plate is composed of Middle Cambrian through Ordovician carbonate rocks. Oriel and Platt (1979) implied that the carbonate plate is structurally continuous with a plate of correlative strata similarly bounded by low-angle normal faults in the Raft River and Albion Mountains $100 \mathrm{~km}$ to the west (Fig. 21). A provocative observation is that low-angle faults in the Bannock Range preferentially eliminate predominantly shaly units that are stratigraphically equivalent to strata eliminated or thinned by extension faults in the Sheeprock Mountains (the Kelley Canyon Formation and the Lower Cambrian Pioche Shale; Fig. 5). One interpretation is that prior to late Cenozoic disruption, the "thrust plates" identi- fied by Oriel and Platt (1979) extended continuously from southern Idaho to central Utah. However, my preferred interpretation is that low-angle faults of the southern Bannock Range and Sheeprock Mountains are only locally developed extension faults of probable late Cenozoic (and/or perhaps mid-Cenozoic) age. In different places, the faults may independently have initiated within mechanically weak stratigraphic units that happen to be regionally persistent (see Fig. 19).

\section{CONCLUSIONS}

The internal structure of the southern Sheeprock Mountains is dominated by gently dipping thrusts and extension faults. The Sheeprock Thrust juxtaposes Upper Proterozoic strata above beds of Paleozoic age with a stratigraphic separation exceeding $10 \mathrm{~km}$, and underlies much of the range. The Pole Canyon Thrust is interpreted as an imbrication in the upper plate of the Sheeprock Thrust, and occurs only north of the east-northeast-striking Indian Springs (tear) Fault. The recumbent Pole Canyon Anticline originated through propagation of the thrusts. Tectonic transport inferred parallel to the Indian Springs Fault is corroborated by the vergence of the Pole Canyon Anticline, the direction in which the Sheeprock Thrust ramps upward, a separation arc plot of asymmetrical folds, and the orientation of slickensides on the Pole Canyon Thrust.

The principal extension faults are the Harker and Lion Hill Faults, which together account for stratigraphic omission of as much as several kilometres. Their slip direction is poorly constrained as approximately toward the north or northeast.

The thrust faults deform Pennsylvanian rocks and are cut by igneous rocks of probable Oligocene-Miocene age. Regional arguments suggest deformation in latest Jurassic to Early Cretaceous time. Fault geometry suggests that the extension faults are younger than the thrusts and probably of late Cenozoic age. However, the possibility of midCenozoic or even earlier displacement on the extension faults cannot be entirely ruled out. My preferred interpretation of these faults could be tested through deep drilling or acquisition of seismic reflection profiles north of the range.

The suggested timing of deformation in the southern Sheeprock Mountains is consistent with the view that there was minimal regional extension before middle Cenozoic time and that crustal shortening in the fold-thrust belt is for the most part unrelated to hinterland extension.

\section{ACKNOWLEDGMENTS}

This paper is a by-product of a regional study of Upper Proterozoic glacial deposits in northwestern Utah, supported by National Science Foundation grants ATM 7424201, EAR 77-06008, and EAR 78-15194 to J. C. Crowell. 
Although the project was aimed primarily at reconstructing the ancient glacial facies, mapping in the Sheeprock Mountains led to new interpretations of both the Proterozoic stratigraphy and the geologic structure of that range.

It is particularly appropriate that a paper on the latter topic should appear in a volume dedicated to Max Crittenden, to whom I am indebted for many stimulating discussions in the field. He is to be credited with the idea that puzzling stratigraphic and structural relations that $I$ had observed along the northeast flank of the Sheeprock Mountains are due to substantial stratigraphic omission on low-angle faults, an interpretation borne out by subsequent mapping. I also thank T. R. Bultman and C. C. Wielchowsky for discussions about deformational mechanisms in fold-thrust belts, and R. G. Bohannon, S. H. Lingrey, D. M. Miller, and H. T. Morris for helpful criticisms that measurably improved the manuscript. All drafts were typed by Donna Kelly. Publication has been approved by Exxon Production Research Company.

\section{REFERENCES CITED}

Allmendinger, R. W, and Jordan, T. E., 1981, Mesozoic evolution, hinterland of the Sevier orogenic belt: Geology, v. 9, p. 308-313.

Armstrong, F. C., and Oriel, S. S., 1965, Tectonic development of ldahoWyoming thrust belt: American Association of Petroleum Geologists Bulletin, v. 49 , p. $1847-1866$

Armstrong, R. L., 1968, Sevier orogenic belt in Nevada and Utah: Geological Society of America Bulletin, v. 79, p. 429-458.

1970, Geochronology of Tertiary igneous rocks, eastern Basin and Range province, western Utah, eastern Nevada, and vicinity, U.S.A. Geochimica et Cosmochimica Acta, v. 34, p. 203-232.

1972, Low-angle (denudation) faults, hinterland of the Sevier orogenic belt, eastern Nevada and western Utah: Geological Society of America Bulletin, v, 83, p. 1729-1754

Bates, R. L., and Jackson, J. A., eds., 1980, Glossary of geology (second edition): Virginia, American Geological Institute, $749 \mathrm{p}$.

Blick, N. H., 1979, Stratigraphic, structural and paleogeographic interpretation of upper Proterozoic glaciogenic rocks in the Sevier orogenic belt, northwestern Utah [Ph.D. dissertation]: Santa Barbara, University of California, $633 \mathrm{p}$.

Burchfiel, B. C., and Davis, G. A., 1975, Nature and controls of Cordilleran orogenesis, western United States: Extensions of an earlier synthesis: American Journal of Science, v. 275-A, p. 363-396

Burchfiel, B. C., and Hickcox, C. W., 1972, Structural development of central Utah, in Baer, J. L., and Callaghan, E., eds., Plateau-Basin and Range transition zone, central Utah: Utah Geological Association Publication 2, p. 55-66.

Chapple, W. M., 1978, Mechanics of thin-skinned fold-and-1hrust belts: Geological Society of America Bulletin, v. 89, p. 1189-1198.

Christie-Blick, N., 1982, Upper Proterozoic and Lower Cambrian rocks of the Sheeprock Mountains, Utah: Regional correlation and significance: Geological Society of America Bulletin, v. 93, p. 735-750.

Cohenour, R. E., 1959, Sheeprock Mountains, Tooele and Juab Counties: Precambrian and Paleozoic stratigraphy, igneous rocks, structure. geomorphology, and economic geology: Utah Geological and Mineralogical Survey Bulletin 63, $201 \mathrm{p}$.

- 1970, Sheeprock Granite, in Whelan, J. A., compiler, Radioactive and isotopic age determinations of Utah rocks: Utah Geological and Mineralogical Survey Bulletin 81, p. 31.
Compton, R. R., and Todd, V. R., 1979, Oligacene and Miocene metamorphism, folding, and low-angle faulting in northwestern Utah: Reply: Geological Society of America Bulletin, v. 90, p. 307-309.

Compton, R. R., Todd, V. R., Zartman, R. E., and Naeser, C. W., 1977, Oligocene and Miocene metamorphism, folding, and low-angle faulting in northwestern Utah: Geological Society of America Bulletin, v. 88, p. $1237-1250$.

Coney, P. J, 1980, Cordilleran metamorphic core complexes: An overview, in Crittenden, M. D., Jr, Coney, P. J., and Davis, G. H., eds., Cordilleran metamorphic core complexes: Geological Society of America Memoir 153, p. 7-31.

Crittenden, M. D., Jr.. 1976, Stratigraphic and structural setting of the Cottonwood area, Utah, in Hill, J. G., ed., Geology of the Cordilleran hingeline: Rocky Mountain Association of Geologists, Symposium, p. 363-379.

1979, Oligocene and Miocene metamorphism, folding, and low-angle faulting in northwestern Utah: Discussion: Geological Society of America Bulletin, v. 90, p. 305-306.

1980, Metamorphic core complexes of the North American Cordillera: Summary, in Crittenden, M. D., Jr., Coney, P. J., and Davis, G. H., eds., Cordilleran metamorphic core complexes: Geological Society of America Memoir 153, p. 485-490.

Crittenden, M. D., Ir., Schaeffer, F. E., Trimble, D. E., and Woodward, L. A., 1971, Nomenclature and correlation of some upper Precambrian and basal Cambrian sequences in western Utah and southeast. ern Idaho: Geological Society of America Bulletin, v. 82, p. 581-602.

Crittenden, M. D., Jr, Christie-Blick, N., and Link, P. K., 1983, Evidence for two pulses of glaciation during the late Proterozoic in northern Utah: Geological Society of America Bulletin, in press.

Crowell, J. C., 1959, Problems of fault nomenclature: American Association of Petroleum Geologists Bulletin, v. 43, p. 2653-2674.

Dahlstrom, C.D.A., 1970, Structural geology in the eastern margin of the Canadian Rocky Mountains: Bulletin of Canadian Petroleum Geology, v. 18, p. 332-406.

Davis, G. A., Anderson, J. L., Frost, E. G., and Shackelford, T. J., 1980, Mylonitization and detachment faulting in the Whipple-BuckskinRawhide Mountains terrane, southeastern California and western Arizona, in Crittenden. M. D., Jr., Coney, P. J., and Davis, G. H., eds., Cordilleran metamorphic core complexes: Geological Society of America Memoir 153, p. 79-129.

de Sitter, L. U., 1964, Structural geology: New York; McGraw-Hill, $551 \mathrm{p}$.

Eardley, A. J, 1939, Structure of the Wasatch-Great Basin region: Geological Society of America Bulletin, v. 50, p. 1277-1310.

Eardley, A. J., and Hatch, R. A., 1940, Proterozoic(?) rocks in Utah: Geological Society of America Bulletin, v. 51, p. 795-843.

Gardner, W. C., 1954, Geology of the West Tintic mining district and vicinity, Juab County, Utah [M.S. thesis]: Salt Lake City, University of Utah, $43 p$

Groff, S. L., 1959, Geology of the West Tintic Range and vicinity, Tooele and Juab Counties, Utah [Ph.D. thesis]: Salt Lake City, University of Utah, $183 \mathrm{p}$.

Hansen, E., 197I, Strain facies: New York, Springer-Verlag, 208 p.

Harris, D., 1958, The geology of Dutch Peak area, Sheeprock Range, Tooele County, Utah: Brigham Young University, Research Studies, Geology Series, v. 5, no. I, 82 p.

Harrison, J. E., and Peterman, Z. E., 1980, North American Commission on Stratigraphic Nomenclature Note 52-A preliminary proposal for a chronometric time scale for the Precambrian of the United States and Mexico: Geological Society of America Bulletin, Part 1, v, 91, p. $377-380$

Hill, M. L., 1959, Dual classification of faults: American Association of Petroleum Geologists Bulletin, v. 43, p. 217-237.

Hintze, L. F., 1973, Geologic history of Utah: Brigham Young University 
Geology Studies, v. 20, pt. 3, 181 p.

Hintze, L. F., and Robison, R. A., 1975, Middle Cambrian stratigraphy of the House, Wah Wah, and adjacent ranges in western Utah: Geological Society of America Bulletin, v. 86, p. 881-891.

Hose, R. K., and Danes, Z. F., 1973, Development of the late Mesozoic to early Cenozoic structures of the eastern Great Basin, in de Jong, K. A., and Scholten, R., eds., Gravity and tectonics: New York, John Wiley and Sons, p. 429-441.

James, H. L., 1972, Stratigraphic Commission Note 40-Subdivision of Precambrian: An interim scheme to be used by U.S. Geological Survey: American Association of Petroleum Geologists Bulletin, v. 56, p. $1128-1133$.

-.. 1978, Subdivision of the Precambrian-a brief review and a report on recent decisions by the Subcommission on Precambrian Stratigraphy: Precambrian Research, v. 7, p. 193-204.

King, P. B., 1969, The tectonics of North America -a discussion to accompany the tectonic map of North America, scale 1:5,000,000: U.S. Geological Survey Professional Paper 628, $95 \mathrm{p}$.

Lindsey, D. A., Naeser, C. W., and Shawe, D. R., 1975, Age of volcanism, intrusion, and mineralization in the Thomas Range, Keg Mountain, and Desert Mountain, western Utah: U.S. Geological Survey Journal of Research, v. 3, p. 597-604.

Link, P. K, 1980, Younger-over-older thrust fault reactivated as landslide surface, Oxford Mountain, Bannock Range, southeastern Idaho [abs.]: Geological Society of America Abstracts with Programs, v. 12, no. 3 , p. 116.

- 1981, Geometry of younger-over-older thrusts and high-angle normal faults, Oxford Mountain, Bannock Range, southeast ldaho [abs.]: Geological Society of America Abstracts with Programs, v. 13, no. 2, p. 67.

1982, Geology of the Upper Proterozoic Pocatello Formation, Bannock Range, southeastern Idaho [Ph.D. dissertation]: Santa Barbara, University of California, $131 \mathrm{p}$.

Lipman, P. W., Prostka, H. J., and Christiansen, R. L., 1972, Cenozoic volcanism and plate-tectonic evolution of the western United States. 1. Early and Middle Cenozoic: Philosophical Transactions of the Royal Society of London A, v. 271, p. 217-248.

Loughlin, G. F, 1920, Sheeprock Mountains, in Butler, B. S., Loughlin, G. F. Heikes, V. C., and others, The ore deposits of Utah: U.S. Geological Survey Professional Paper 111, p. 423-444.

McClay, K. R., 1981, What is a thrust? What is a nappe?, in McClay, K. R., and Price, N. J., eds., Thrust and nappe tectonics: Geological Society of London Special Publication 9, p. 7-9.

McKee, E. H., 1971, Tertiary igneous chronology of the Great Basin of western United States - Implications for tectonic models: Geological Society of America Bulletin, v. 82, p. 3497-3502.

Miller, D. M., 1980, Structural geology of the northern Albion Mountains, south-central ldaho, in Crittenden, M. D., Jr., Coney, P. J., and Davis, G. H., eds., Cordilleran metamorphic core complexes: Geological Society of America Memoir 153, p. 399-423.

Moore, W. J., and Sorensen, M. L., 1979. Geologic map of the Tooele $1^{\circ}$ by $2^{\circ}$ quadrangle, Utah: U.S. Geological Survey Miscellaneous Investigations Series, Map 1-1132, scale 1:250,000.

Moores, E. M., Scott, R. B., and Lumsden, W. W., 1970, Tertiary tectonics of the White Pine-Grant Range region, east-central Nevada, and some regional implications: Reply: Geological Society of America Bulletin, v. 81, p. 323-330.

Morris, H. T., 1977, Geologic map and sections of the Furner Ridge Quadrangle, Juab County, Utah: U.S. Geological Survey, Map 11045, scale 1:24,000.

Morris, H. T., and Kopf, R. W., 1967, Breccia pipes in the West Tintic and Sheeprock Mountains, Utah: U.S. Geological Survey Professional Paper 575-C, p. 66-71.

-. 1969, Tintic Valley thrust and associated low-angle faults, central Utah [abs.]: Geological Society of America Abstracts with Programs, v. 1, no. 5, p. $55-56$.

- 1970a, Preliminary geologic map and cross section of the Cherry Creek Quadrangle and adjacent part of the Dutch Peak Quadrangle, Juab County, Utah: U.S. Geological Survey Open-File Map, scale $1: 24,000$.

$1970 \mathrm{~b}$, Preliminary geologic map and cross section of the Maple Peak Quadrangle and adjacent part of the Sabie Mountain Quadrangle, Juab County, Utah: U.S. Geological Survey Open-File Map, scale $1: 24,000$.

Morris, H. T., and Lovering, T. S., 1961, Stratigraphy of the East Tintic Mountains, Utah: U.S. Geological Survey Professional Paper 361, $145 \mathrm{p}$.

Morris, H. T., and Shepard, W. M., 1964, Evidence for a concealed tear fault with large displacement in the central East Tintic Mountains, Utah: U.S. Geological Survey Professional Paper 501-C, p. 19-21.

Oriel, S. S., and Armstrong, F. C., 1966, Times of thrusting in IdahoWyoming thrust belt: Reply: American Association of Petroleum Geologists Bulletin, v. 50, p. 2614-2621.

Oriel, S. S., and Platt, L. B., 1979, Younger-over-older thrust plates in southeastern Idaho [abs.]: Geological Society of America Abstracts with Programs, v. 11, no. 6, p. 298.

Price, R. A., 1981, The Cordilleran foreland thrust and fold belt in the southern Canadian Rocky Mountains, in McClay, K. R., and Price, N. J., eds., Thrust and nappe tectonics: Geological Society of London Special Publication 9, p. 427-447.

Rehrig, W. A., and Reynolds, S. J., 1980, Geologic and geochronologic reconnaissance of a northwest-trending zone of metamorphic core complexes in southern and western Arizona, in Crittenden, M. D., Jr., Coney, P. J., and Davis, G. H., eds., Cordilleran metamorphic core complexes: Geological Society of America Memoir 153, p. $131-157$.

Roberts, R. J., Crittenden, M. D., Jr, Tooker, E. W., Morris, H. T., Hose, R. K., and Cheney, T. M., 1965, Pennsylvanian and Permian basins in northwestern Utah, northeastern Nevada and south-central Idaho: American Association of Petroleum Geologists Bulletin, v. 49, p. 1926-1956.

Royse, F., Jr., Warner, M. A., and Reese, D. L., 1975, Thrust belt structural geometry and related stratigraphic problems, Wyoming-ldahonorthern Utah, in Bolyard, D. W., ed., Deep drilling frontiers of the central Rocky Mountains: Rocky Mountain Association of Geologists, Symposium, p, 4l-54.

Stewart, J. H., 1980, Regional tilt patterns of late Cenozoic basin-range fault blocks, western United States: Geological Society of America Bulletin, Part I, v. 91, p. 460-464.

Stokes, W. L., compiler, 1963, Geologic map of northwestern Utah: Salt Lake City, University of Utah, College of Mines and Mineral Industries.

Stringham, B. F, 1942, Mineralization in the West Tintic mining district, Utah: Geological Society of America Bulletin, v. 53, p. 267-290.

Suppe, J., 1979, Fault-bend folding [abs.]: Geological Society of America Abstracts with Programs, v. 11, no. 7, p. 525.

Thomas, G. H.. 1958. The geology of Indian Springs Quadrangle, Tooele and Juab Counties, Utah [M.S. thesis]: Provo, Brigham Young University, $35 \mathrm{p}$.

Wernicke, B., 1982, Mesozoic evolution, hinterland of the Sevier orogenic belt: Comment: Geology, v. 10, p. 3-5.

Winslow, M. A., 1981, Mechanisms for basement shortening in the Andean foreland fold belt of southern South America, in McClay, $\mathrm{K}$. R, and Price, N. J., eds., Thrust and nappe tectonics: Geological Society of London Special Publication 9, p. 513-528.

Manuseript ACCePted by tue SOCIETy August 20, 1982

Printed in U.S.A. 